NBER WORKING PAPER SERIES

\title{
THE IMPACTS OF ENVIRONMENTAL REGULATIONS ON INDUSTRIAL ACTIVITY: EVIDENCE FROM THE 1970 AND 1977 CLEAN AIR ACT AMENDMENTS AND THE CENSUS OF MANUFACTURES
}

\author{
Michael Greenstone \\ Working Paper 8484 \\ http://www.nber.org/papers/w8484 \\ NATIONAL BUREAU OF ECONOMIC RESEARCH \\ 1050 Massachusetts Avenue \\ Cambridge, MA 02138 \\ September 2001
}

This research was carried out while the author was a research associate at the Census Bureau's Center for Economic Studies in Suitland, MD. All papers are screened to ensure that they do not disclose confidential information. I am indebted to Orley Ashenfelter, David Card, Kenneth Chay, James Heckman, David Lee, Paul Oyer, Katherine Ozment, Robert Topel and an anonymous referee for especially valuable comments. The paper also benefited from discussions with Tim Dunne, Henry Farber, Wayne Gray, John Haltiwanger, Vernon Henderson, Alan Krueger, Helen Levy, John McClelland, Harvey Rosen, Michael Rothschild, Cecilia Rouse, Christopher Timmins, and Ken Troske. Numerous seminar participants made very helpful suggestions and comments. Robert Bechtold, John Haltiwanger, and Arnie Reznek were especially generous with their time in helping me obtain access to the LRD. Vernon Henderson and Randy Becker graciously allowed me to photocopy parts of the Code of Federal Regulations. The EPA district office in Philadelphia complied with my freedom of information act request in a timely fashion. Richard Brooks, Emily Johnson, Steve Luk, and Ryan Montgomery provided outstanding research assistance. Generous financial support was provided by the Alfred P. Sloan Foundation's Doctoral Dissertation Fellowship, Resources for the Future's Joseph L. Fisher Dissertation Award and at Princeton University by the Center for Economic Policy Studies, the Industrial Relations Section, and the Graduate School's Summer Fellowship. The views expressed herein are those of the author(s) and not necessarily those of the National Bureau of Economic Research or the U.S. Bureau of the Census.

(C) 2001 by Michael Greenstone. All rights reserved. Short sections of text, not to exceed two paragraphs, may be quoted without explicit permission provided that full credit, including $\mathrm{C}$ notice, is given to the source. 
The Impacts of Environmental Regulations on Industrial Activity:

Evidence from the 1970 and 1977 Clean Air Act Amendments and the Census of Manufactures

Michael Greenstone

NBER Working Paper No. 8484

September 2001

\begin{abstract}
$\underline{\text { ABSTRACT }}$
This paper estimates the effects of environmental regulations on industrial activity. The analysis is conducted with the most comprehensive data available on both regulations from the Clean Air Act Amendments' division of counties into pollutant-specific nonattainment and attainment categories and manufacturing activity from the 1.75 million plant observations that comprise the 1967-87 Censuses of Manufactures. Emitters of the controlled pollutants are subject to greater regulatory oversight in nonattainment counties. I find that in the first 15 years after the Amendments became law (1972-1987), nonattainment counties (relative to attainment ones) lost approximately 590,000 jobs, $\$ 37$ billion in capital stock, and $\$ 75$ billion (1987\$) of output in pollution intensive industries. These estimates are derived from a statistical model for plant-level growth that controls for plant fixed effects, unrestricted industry shocks, and unrestricted county shocks. Importantly these findings are robust across many specifications, and the effects are apparent across a wide range of polluting industries. Although the decline in manufacturing activity was substantial in nonattainment counties, it was modest compared to the size of the entire manufacturing sector.
\end{abstract}

Michael Greenstone

Department of Economics

University of Chicago

1126 E. $59^{\text {th }}$ St.

Chicago, IL 60637

and NBER

mgreenst@midway.uchicago.edu 


\section{Introduction}

Efforts to regulate pollution are among the most controversial interventions mandated by the federal government. This controversy is partially generated by the lack of convincing evidence on their costs. The Pollution Abatement Costs and Expenditures Survey reports that manufacturing plants spend almost \$30 billion a year to comply with environmental regulations (U.S. Bureau of the Census 1993). Manufacturers contend that these expenditures place them at a competitive disadvantage in the global economy and leads to the loss of tens of thousands of U.S. jobs. But previous empirical research is unable to consistently translate industry's claims into observable declines in manufacturing activity (Bartik 1988; McConnell and Schwab 1990; Gray and Shadbegian 1995; Jaffe et al. 1995; Henderson 1996; Levinson 1996; Becker and Henderson 2000 and 2001). In fact, some research suggests that environmental regulations do not harm regulated firms or their workers and may even benefit them (Porter and van der Linde 1995; Bovenberg and van der Ploeg 1996; Berman and Bui 1997; Berman and Bui 1998). In order to set rational policy, it is crucial to understand whether these regulations restrict industrial activity. ${ }^{1}$

This paper presents new evidence about this relationship by focusing on the Clean Air Act's impact on polluting manufacturers. The Clean Air Act, originally passed in 1963 and amended in 1970, 1977, and 1990, is one of the most significant federal interventions into the market in the post-War period. Following the passage of the 1970 Amendment, the Environmental Protection Agency (EPA) established separate national ambient air quality standards -- a minimum level of air quality that all counties are required to meet -- for four criteria pollutants: carbon monoxide $(\mathrm{CO})$, tropospheric ozone $\left(\mathrm{O}_{3}\right)$, sulfur dioxide $\left(\mathrm{SO}_{2}\right)$, and total suspended particulates (TSPs). As a part of this legislation, every U.S. county receives nonattainment or attainment designations for each of the four pollutants annually. The nonattainment designation is reserved for counties whose air contains concentrations of the relevant pollutant that exceed the federal standard. Emitters of the regulated pollutant in nonattainment counties are subject to greater regulatory oversight than emitters in attainment counties. Non-polluters are free from regulation in both categories of counties.

This paper brings together a variety of comprehensive data files to determine empirically the

\footnotetext{
${ }^{1}$ See Chay and Greenstone (2000 and 2001b) for estimates of the benefits associated with the Clean Air Act Amendments.
} 
effects of these federally mandated county-level regulations on the activity of polluting manufacturers in the 1967-1987 period. I compiled annual data on the four pollutant-specific, nonattainment/attainment designations for each of the 3,070 U.S. counties from the Code of Federal Regulations and EPA pollution monitors. The structure of this longitudinal, regulation data allows for the identification of cross-sectional variation in these regulations, as well as changes in counties' pollutant-specific regulatory status over time. Despite the centrality of these county-level regulations to environmental policy, this is the first time that either a researcher or the EPA has produced a data file with these designations for all four of these criteria pollutants. ${ }^{2}$ The regulation file is merged with the 1.75 million plant-level observations from the microdata in the 1967-1987 Censuses of Manufactures (CMs), which asks detailed questions about plants' characteristics (including county of location), input usage, and output. The combined data file is used to relate the growth of employment, investment, and shipments of manufacturers to the federally mandated regulations across the entire country.

The paper's approach overcomes at least some of the objections to earlier studies of the impact of environmental regulations. First, the least restrictive statistical model for the growth of the measures of plant-level manufacturing activity controls for plant fixed effects, unrestricted industry shocks, and unrestricted county shocks. The estimated regulation effects are therefore purged of all permanent plant characteristics that determine growth, all transitory differences in the mean growth of plants across industries, and all transitory determinants of growth that are common to polluters and non-polluters within a county. These controls are important because this period was one of dramatic changes in the manufacturing sector, including a substantial increase in competition from foreign countries in some industries, a secular movement of plants from the Rust Belt to the South, and two oil price shocks that had differential effects on particular industries and regions.

Second, this paper uses the principal instruments of the Clean Air Act Amendments (CAAAs), the pollutant-specific, county-level attainment/nonattainment designations, as its measures of regulation. These four designations are the "law of the land" and capture the regional and industry variation that Congress imposed with this legislation. ${ }^{3}$ In fact, these designations govern the writing and enforcement

2 McConnell and Schwab (1990), Henderson (1996) and Becker and Henderson (2000 and 2001) use $\mathrm{O}_{3}$ nonattainment status but did not collect information on nonattainment status for the other pollutants.

${ }^{3}$ A few states and localities (e.g., California) have imposed regulations that are stricter than the federal ones. Any regulations over and above the federally mandated ones are unobserved variables in the subsequent analysis. This paper estimates the average effect 
of the plant-specific regulations that restrict the behavior of polluters. Moreover, the simultaneous evaluation of all four regulations is important, because many plants emitted multiple pollutants and many counties were designated nonattainment for multiple pollutants. The use of these regulations should address Jaffe, et al.'s (1995) concern that previous studies rely on measures of regulation that are too aggregated (e.g., state-level measures) to detect differences in stringency.

Third, the detailed CMs questionnaire allows for an examination of regulation's impact across a number of outcomes and categories of plants. The previous literature generally focuses on the effects of regulation on a single outcome variable (e.g., employment) or on a particular category of plants (e.g., the location decisions of new plants). The focus on a single outcome, or on a particular category of plant, leaves open the possibility that the effects of regulation are not fully explored. In contrast, this paper examines the impacts of regulation on the growth of employment, capital stock, and shipments. Moreover, the paper's estimates are derived from a sample that includes existing plants as well as newly opened ones.

The results indicate that the CAAAs substantially retarded the growth of polluting manufacturers in nonattainment counties. The estimates suggest that in the first 15 years after the Amendments became law (i.e., 1972-1987), nonattainment counties (relative to attainment ones) lost approximately 590,000 jobs, $\$ 37$ billion in capital stock, and $\$ 75$ billion (1987\$) of output in pollution-intensive industries. Importantly, these findings are robust across many specifications and the effects are apparent across a wide range of polluting industries. Although the decline in manufacturing activity was substantial in nonattainment counties, it was modest compared to the size of the entire manufacturing sector.

The paper proceeds as follows. Section II describes the statutory requirements of the CAAAs and the variation in regulation that they imposed. Section III describes the data and presents some summary statistics on the regulations' scope. Section IV presents the identification strategy, and section $\mathrm{V}$ discusses the estimation results. Section VI develops two measures of the magnitude of the regulations' impacts and interprets the results. Section VII concludes the paper.

\section{The CAAAs and the Variation in Regulation}

The ideal analysis of the relationship between industrial activity and environmental regulations involves a controlled experiment in which environmental regulations are randomly assigned to plants. 
Then, the changes in activity among the regulated and unregulated can be compared with confidence that any differences are causally related to regulation. In the absence of such an experiment, an appealing alternative is to find a situation where similar plants face different levels of regulation.

The structure of the 1970 and 1977 CAAAs may provide such an opportunity. In particular, the Amendments introduce substantial cross-sectional and longitudinal variation in regulatory intensity at the county level. This section describes the CAAAs and why how they may offer the opportunity to credibly identify the relationship between environmental regulation and industrial activity.

\section{A. The CAAAs and their Enforcement}

Before 1970 the federal government did not play a significant role in the regulation of air pollution; that responsibility was left primarily to state governments. In the absence of federal legislation, few states found it in their interest to impose strict regulations on polluters within their jurisdictions. Disappointed with the persistently high concentrations of $\mathrm{O}_{3}{ }^{4}, \mathrm{SO}_{2}, \mathrm{TSPs}^{5}$, and $\mathrm{CO}$ and concerned about their detrimental health impacts ${ }^{6}$, Congress passed the 1970 Clean Air Act Amendments. ${ }^{7}$

The centerpiece of this legislation is the establishment of separate federal air quality standards for each of the pollutants, which all counties are required to meet. Appendix Table 1 lists these air quality standards. The stated goal of the Amendments is to bring all counties into compliance with the standards by reducing local air pollution concentrations. The legislation requires the EPA to assign annually each county to either nonattainment or attainment status for each of the four pollutants, based on whether the relevant standard is exceeded.

The CAAAs direct the fifty states to develop and enforce local pollution abatement programs that

\footnotetext{
${ }^{4}$ There are separate standards for $\mathrm{O}_{3}$ and nitrogen dioxide $\left(\mathrm{NO}_{2}\right)$, and, in principle, a county could meet one of these standards, but not the other. However, $\mathrm{O}_{3}$ is the result of a complicated chemical process that involves $\mathrm{NO}_{2}$ and the vast majority of counties that were nonattainment for $\mathrm{NO}_{2}$ were also nonattainment for $\mathrm{O}_{3}$. As a result, I designated a county nonattainment for $\mathrm{O}_{3}$ if the EPA labeled it nonattainment for either $\mathrm{O}_{3}$ or $\mathrm{NO}_{2}$. All future references to $\mathrm{O}_{3}$ refer to this combined measure.

${ }^{5}$ In 1987 the EPA changed its focus from the regulation of all particulates (i.e., TSPs) to the smaller $\mathrm{PM}_{10}$ s, which have an aerodynamic diameter equal to or less than 10 micrometers. In 1997 the $\mathrm{PM}_{10}$ regulation was replaced with a $\mathrm{PM}_{2.5}$ one.

${ }^{6}$ See Dockery et al. (1993), Ransom and Pope (1995), and Chay and Greenstone (2001a and 2001b) on the relationship between air pollution and human health.

${ }^{7}$ See Lave and Omenn (1981) and Liroff (1986) for more detailed histories of the CAAAs.
} 
ensure that each of their counties attains the standards. In their nonattainment counties, states are required to develop plant-specific regulations for every major source of pollution. These local rules demand that substantial investments, by either new or existing plants, are accompanied by installation of state-of-the-art pollution abatement equipment and by permits that set emissions ceilings. The 1977 Amendments added the requirement that any increase in emissions from new investment be offset by a reduction in emissions from another source within the same county. ${ }^{8}$ States are also mandated to set emission limits on existing plants in nonattainment counties.

In attainment counties, the restrictions on polluters are less stringent. Large scale investments require less expensive (and less effective) pollution abatement equipment; moreover, offsets are not necessary. Smaller investments and existing plants are essentially unregulated. Additionally, nonpolluters are free from regulation in both sets of counties.

Both the states and the federal EPA are given substantial enforcement powers to ensure that the CAAAs' intent is met. For instance, the federal EPA must approve all state regulation programs in order to limit the variance in regulatory intensity across states. On the compliance side, states run their own inspection programs and frequently fine non-compliers. The 1977 legislation also made the plantspecific regulations both federal and state law, which gives the EPA legal standing to impose penalties on states that do not aggressively enforce the regulations and on plants that do not adhere to the regulations. A number of studies document the effectiveness of these regulatory actions at the plant level (Nadeau 1997; Cohen 1998). Perhaps, the most direct evidence that the regulations are enforced successfully is that air pollution concentrations declined more in nonattainment counties than in attainment ones during the 1970s and 1980s (Henderson 1996; Chay and Greenstone 2000 and 2001b; Greenstone 2000).

\section{B. Which Industries are Targeted by the CAAAs?}

The four regulated pollutants are emitted by a wide variety of natural and anthropogenic sources of which the manufacturing sector is a primary contributor. Within this sector, the pollutant-specific regulations only apply to emitters of the relevant pollutants. An official list of the emitting industries is unavailable from the EPA, so it is necessary to devise a rule to divide manufacturers into emitters and

\footnotetext{
${ }^{8}$ The reduction in pollution due to the offset has to be larger than the expected increase in pollution associated with the new investment. The offsets could be purchased from a different facility or generated by tighter controls on existing operations at the same site (Vesilind, Peirce, and Weiner 1988).
} 
non-emitters for each of the four pollutants. It is important that this assignment rule is accurate, because the subsequent analysis compares the growth of emitters and non-emitters and misclassification will bias the estimated regulation effects.

After the exploration of a number of alternatives, I use the EPA's estimates of industry-specific emissions (see Appendix Table 2) to determine pollutant-specific emitter status. Industries that account for $7 \%$ or more of industrial sector emissions of that pollutant are designated an emitter; all other industries are considered non-emitters. ${ }^{9}$ This rule aims to mimic the EPA's focus on the dirtiest industries in the initial years of regulation. Its application causes 12 separate industries to be designated as emitters of at least one of the pollutants. The subsequent analysis demonstrates that the estimated effects of the regulations are largely insensitive to other reasonable definitions of emitter status.

Under any rule, each industry could emit any of the 16 (i.e., $2^{4}$ ) possible combinations of the four pollutants. The $7 \%$ assignment rule divides the manufacturing sector such that 8 of the possible combinations are represented. The 7 polluting combinations (with the relevant industry names and SIC codes in parentheses) are emitters of: $\mathrm{O}_{3}$ (Printing 2711-89, Organic Chemicals 2861-9, Rubber and Miscellaneous. Plastic Products 30, Fabricated Metals 34, and Motor Vehicles, Bodies, and Parts 371); $\mathrm{SO}_{2}$ (Inorganic Chemicals 2812-9); TSPs (Lumber \& Wood Products 24); $\mathrm{CO} / \mathrm{SO}_{2}$ (Nonferrous Metals 333-4); $\mathrm{CO} / \mathrm{O}_{3} / \mathrm{SO}_{2}$ (Petroleum Refining 2911); $\mathrm{O}_{3} / \mathrm{SO}_{2} / \mathrm{TSPs}$ (Stone, Clay, Glass, and Concrete 32); and $\mathrm{CO} / \mathrm{O}_{3} / \mathrm{SO}_{2} / \mathrm{TSPs}$ (Pulp and Paper 2611-31 and Iron and Steel 3312-3 and 3321-5). The EPA's estimates of emissions indicate that the remaining industries are not major emitters of any of the four pollutants, and I label these industries Clean. ${ }^{10}$

\section{Summarizing the Variation in Regulation Due to the CAAAs}

\footnotetext{
${ }^{9}$ See the Data Appendix for further details on the determination of pollutant-specific emitting status.

${ }^{10}$ It is informative to compare this division of the manufacturing sector to those in the previous literature. In each of their papers, Henderson (1996) and Becker and Henderson (2000 and 2001) designate different sets of industries as subject to $\mathrm{O}_{3}$ nonattainment status. The current paper's set of ozone emitters spans the intersection of their three sets, with the exception that the 7\% rule excludes Wood Furniture (SIC 2511) and Plastic Materials and Synthesis (SIC 282). Berman and Bui's (1998 and 2001) list of regulated industries is not readily comparable to this paper's list for at least two reasons. First, their list is not pollutant-specific. Second, their papers examine local regulations in the South Coast Air Basin that are over and above federal and state regulations, so their set of regulated industries is likely to be broader than those scrutinized by the federal EPA. Regardless of these issues, there is substantial overlap between their list of industries targeted in the South Coast and the industries that are classified as emitters of at least one pollutant under this paper's assignment rule.
} 
The structure of the CAAAs provides three sources of variation in which plants were affected by the nonattainment designations. This subsection summarizes these three dimensions of variation and highlights their importance from an evaluation perspective. It also briefly discusses some of the sources of this variation and why they may reinforce the credibility of the subsequent analysis.

The first dimension of variation is that at any point in time the pollutant-specific nonattainment designations are reserved for counties whose pollution concentrations exceed the federal standards. This cross-sectional variation allows for the separate identification of industry-specific shocks and the regulation effects. This may be especially important in the 1967-87 period, because there were dramatic shocks (e.g., oil crises, recessions, and increases in foreign competition) that differentially affected industries.

The second dimension of variation is that a county's attainment/nonattainment designations vary over time as its air quality changes. Consequently, individual plants might be subject to regulations in one period but not in a different one. This longitudinal variation allows for the inclusion of plant fixed effects in equations for plant-level growth. Consequently, the paper presents estimated regulation effects that are derived from within plant comparisons under the attainment and nonattainment regulation regimes.

The third dimension of variation is that within nonattainment counties only plants that emit the relevant pollutant(s) are subject to the regulations. This intra-county variation allows for estimation of models that include unrestricted county $\times$ period effects so that time-varying factors common to all plants within a county are not confounded with the effects of regulation. For example, the 1980-82 recession caused polluting and non-polluting manufacturers in Allegheny County, PA (i.e., Pittsburgh) to reduce their operations. Since Allegheny County was designated nonattainment for a number of pollutants in these years, this decline would be falsely attributed to the regulations if the intra-county variation in emitting status were unavailable.

Some of the sources of variation in nonattainment status reinforce the credibility of an evaluation based on the CAAAs. Specifically, the county-level nonattainment designations are federally mandated and therefore may be unrelated to differences in tastes, characteristics, or underlying economic conditions across counties. Moreover, the nonattainment designations depend on whether local pollution levels exceed the federal standards. And while pollution levels are not randomly assigned, scientific 
evidence suggests that during the years under study many counties were designated nonattainment due to pollution that was related to weather patterns - a factor which is unlikely to be related to local manufacturing sector activity. ${ }^{11}$

\section{Data and Overview of the Regulations' Scope}

The subsequent analysis is based on the most comprehensive data available on manufacturing activity and clean air regulations. This section describes the data sources and structure of the data. It also documents the scope of the regulatory program both geographically and within the manufacturing sector. The last part of the section examines whether the characteristics of nonattainment counties and the plants within them are similar to attainment counties and their plants.

\section{A. $\quad$ Data Sources and Structure}

The manufacturing data come from the microdata underlying the five quinquennial Census of Manufactures from 1967-1987. In each census a plant observation contains information on employment, capital stock, total value of shipments, plant age, whether it is part of a multi-unit firm, and whether the observation is due to a survey response or derived from an administrative record. The 4-digit SIC code and county of location are also reported so that data on which pollutants are emitted and nonattainment designations can easily be merged. Importantly, the CMs contain a unique plant identifier, making it possible to follow individual plants over time. ${ }^{12}$

Consecutive CMs are linked to create four periods-- 1967-1972, 1972-1977, 1977-1982, and 1982-1987. A plant observation in an individual period includes information from the CMs at the beginning and end of a period. ${ }^{13}$ Plants that appear in the first census of a period, but not the last are considered "births"; analogously, plants that appear in the last but not the first are designated "deaths."

\footnotetext{
${ }^{11}$ Cleveland, et. al. (1976) and Cleveland and Graedel (1979) document that wind patterns often cause air pollution to travel hundreds of miles and that the concentration of $\mathrm{O}_{3}$ in the air entering the New York region in the 1970s often exceeded the federal standards. Figure $1 \mathrm{~b}$ graphically depicts the counties that were designated nonattainment for $\mathrm{O}_{3}$ and reveals that virtually the entire Northeast, even counties without substantial local production of $\mathrm{O}_{3}$, is $\mathrm{O}_{3}$ nonattainment for at least one period. It is evident that this region's nonattainment designations partially reflect its location downwind from heavy $\mathrm{O}_{3}$ emitters in the Ohio Valley.

${ }^{12}$ See the appendix in Davis, Haltiwanger, and Schuh (1996) for a more thorough description of the CMs.

${ }^{13}$ Approximately .5\% of plants change SIC codes in a period. Plants are equally likely to switch into and out of emitting industries, so it does not appear that they alter their SIC code to evade regulation.
} 
Plants that appear in both censuses of a period are labeled "stayers."14 There are 1,737,753 plant observations in these four periods.

Each of the 3,070 counties is assigned four pollutant-specific attainment/nonattainment designations in every period. A county's pollutant-specific designation in a given period is based on its attainment/nonattainment status in the first year of that period (e.g., 1982 determines the regulatory status for the 1982-1987 period). All counties are attainment in the 1967-1972 period, because the CAAAs were not in force until the end of this period. The attainment/nonattainment designations for the 19771982 and 1982-1987 periods are determined from the list of nonattainment counties in the Code of Federal Regulations $(C F R)$ in the first year of those periods. ${ }^{15}$ The $C F R$ does not list the identity of the nonattainment counties in the early 1970s and the EPA does not maintain a historical record of them. Consequently, I filed a freedom of information act request and obtained data from the EPA's national pollution monitoring network for these years. For the 1972-1977 period, a county is labeled nonattainment for a pollutant if it had a pollution monitor reading that exceeded the relevant federal standard in 1972. The Data Appendix provides more details on the determination of nonattainment/attainment status.

There are at least two reasons that this definition of the regulation variables is preferable to alternatives based on nonattainment status later in a period. First, it is unlikely that plants can quickly change their production processes in response to regulation. Second, Berman and Bui (1998 and 2001) document that the plant level regulations associated with nonattainment status often set compliance dates a number of years in advance. ${ }^{16}$

\footnotetext{
${ }^{14}$ The permanent plant identifier and the criteria specified by Davis, Haltiwanger, and Schuh (1996) are used to determine whether a period-specific plant observation qualifies as a birth, death, or stayer. The distribution of plants across these categories is $29 \%$ births, $27 \%$ deaths, and $44 \%$ stayers.

${ }^{15}$ The publication of nonattainment counties in the CFR only begins in 1978, so this year determines the 1977-1982 designations.

${ }^{16}$ The determination of nonattainment status from a single year might cause measurement error in the regulation variables, leading to attenuation bias in the estimated effects of regulation. In order to explore this possibility, I experimented with designating a county nonattainment if it received this designation in the first or second year of a period or the year before a period begins. (In the case of the 1982-1987 period, this is 1981, 1982, or 1983.) I also used the total number of years during the period that the county is designated nonattainment as a measure of regulation. The paper's qualitative results are unchanged by these alternative classifications.
} 


\section{B. $\quad$ The Scope of the Clean Air Act Amendments}

Table 1 reports summary information on the incidence of the pollutant-specific nonattainment designations. The first column lists the number of counties designated nonattainment for each pollutant, period by period. It is apparent that the $\mathrm{O}_{3}$ and TSPs regulatory programs are the most pervasive.

The second column details the number of counties that switch from attainment to nonattainment between periods, while the third column enumerates the changes from nonattainment to attainment. It is evident that there is substantial movement into and out of nonattainment status between periods. A summary measure of these changes is that of the 945 counties that are designated nonattainment for at least one of the pollutants, only 21 retain the same designations for all four pollutants throughout the three periods that the CAAAs are in force. These movements in regulatory status reflect a number of factors, including: the EPA's increasing awareness of which counties exceeded the federal standards (e.g., the large increase in the number of nonattainment counties between 1972-1977 and 1977-1982, particularly in the case of ozone), air quality improvement in nonattainment counties, and deterioration in attainment ones. The changes in nonattainment status are important for identification purposes, because they allow for the estimation of econometric models that include county or plant fixed effects.

Figures 1a-1d graphically summarize the incidence of the four regulation programs. The shading indicates the number of periods a county is designated nonattainment for the relevant pollutant: white for 0 , light gray for 1 , gray for 2 , and black for 3 . By moving back and forth between the maps, it is possible to see that many counties were regulated for more than one pollutant (e.g., parts of Southern California, Arizona, and the Rust Belt). The national scope of the regulatory programs is also evident; all 48 continental states have at least one nonattainment county. ${ }^{17}$

Manufacturers that emit one or more of the regulated pollutants and are located in a county that is nonattainment for the emitted pollutant(s) form the group that are directly targeted by the CAAAs. Table 2 presents the levels of employment for emitters of each of the pollutants and the entire manufacturing sector in the four periods. ${ }^{18}$ The level is calculated as the mean of the levels in the first and last years of a period. The table also separately lists employment in nonattainment and attainment

\footnotetext{
${ }^{17}$ Alaska and Hawaii are excluded from the analysis.

${ }^{18}$ Many plants emit multiple pollutants, so the pollutant-specific rows (e.g., "CO Emitting Plants") of Table 2 are not mutually exclusive. Consequently, summing across the rows within a single period overstates employment in plants that emit any pollutant in that period.
} 
counties within the four categories of emitters by period.

The portion of the manufacturing sector that is an emitter varies across the pollutants. For instance, $\mathrm{O}_{3}$ emitters account for the largest share (roughly $31.7 \%$ ) of total manufacturing employment. The shares for the other polluting industries are $11.2 \%$ for TSPs, $9.3 \%$ for $\mathrm{SO}_{2}$, and $5.5 \%$ for $\mathrm{CO}$. Although they are not shown in Table 3, the ranges for capital stock and shipments are 19.9\% (TSPs emitters) to $46.2 \%\left(\mathrm{O}_{3}\right.$ emitters) and $10.7 \%$ (TSPs emitters) to $37.9 \%\left(\mathrm{O}_{3}\right.$ emitters), respectively. Regardless of the measure, it is apparent that the pollutant-specific regulations are directed at industries that account for a substantial proportion of the manufacturing sector.

Table 2 also documents that within the four sets of emitting plants, a meaningful share of employment is located in both attainment and nonattainment counties. Consequently, it may be possible to obtain precise estimates of the effects of the pollutant-specific nonattainment designations.

\section{Are Attainment and Nonattainment Counties "Similar"?}

An important question is whether the nonattainment counties and their polluting plants differ from attainment counties and the polluters within their boundaries. If these two groups are "similar," then the attainment counties may form a valid counterfactual for what would have happened to the nonattainment counties in the absence of regulation. While it is impossible to make any statements about unobserved characteristics, it is instructive to examine observable ones as they provide some guidance on the reliability of the comparisons that underlie the estimated regulation effects. Further to the extent that differences are evident, these comparisons inform the choice of statistical model. This subsection compares counties that are nonattainment for CO in the 1972-1977 period with those that are attainment for $\mathrm{CO}$ in the same period. This is only one of the comparisons that underlie the subsequent analysis, but it captures many of the themes that are present in comparisons of nonattainment and attainment counties in different periods and for different pollutants.

Table 3 displays the means of potential determinants of plant-level growth within three categories of counties. These categories are comprised of counties that are: attainment for $\mathrm{CO}$ in the 1972-1977 period (column 1a); attainment for CO in 1972-1977 but CO nonattainment in a later period (column 1b); and CO nonattainment in 1972-1977 (column 2). The first panel of the table presents means of county-level characteristics, while the second panel documents means of the characteristics of 
CO emitting plants.

Columns (1a) and (2) allow for a comparison of all CO attainment counties to CO nonattainment counties in the $1972-77$ period. It is evident that both the county-level and plant-level characteristics differ with nonattainment status. In particular, nonattainment counties have higher population densities, rates of urbanization, average education levels, per capita income, and per capita government revenues. Moreover a smaller fraction of their jobs are in the manufacturing sector, and they have lower poverty rates. Importantly, the average number of $\mathrm{CO}$ emitting plants is substantially higher in nonattainment counties (14.2) than attainment ones (1.0). Further, $\mathrm{CO}$ emitting plants in nonattainment counties are younger, more likely to be part of a multi-establishment firm, and they have fewer employees.

An alternative to using all $\mathrm{CO}$ attainment counties to form the "counterfactual" is to restrict this group to counties that are $\mathrm{CO}$ attainment in 1972 but $\mathrm{CO}$ nonattainment in later periods. A statistical model that includes county fixed effects effectively refines the counterfactual group in this way. Columns (1b) and (2) permit an exploration of the similarity of these two sets of counties. It is evident that this subset of 1972-1977 CO attainment counties is more similar to the nonattainment counties than was the unrestricted set of attainment counties. For example, the column (1b) counties' mean population density, level of education, income per capita, and poverty rate are all closer to the means of these variables in nonattainment counties. However, the average number of $\mathrm{CO}$ emitting plants and characteristics of these plants remain substantially different across these sets of counties.

It is apparent that the nonattainment counties and their $\mathrm{CO}$ emitting plants are not identical to either set of attainment counties. The obvious conclusion is that nonattainment status is not orthogonal to observable county- or plant-level characteristics that may be determinants of plant growth. Moreover, it is plausible that the same is true for unobservable characteristics. Consequently, it is necessary to estimate statistical models that attempt to control for these differences. The next section describes the preferred statistical model and explains its efforts to purge the likely sources of bias, especially those identified here.

\section{Identification Strategy}

In order to explore the effects of the nonattainment designations on the growth of manufacturers' activity, the plant-level data is fit to the following equation: 


$$
\begin{aligned}
\% \Delta \mathrm{E}_{\mathrm{pt}} & =\left(\mathrm{E}_{\mathrm{pt}}-\mathrm{E}_{\mathrm{pt}-5}\right) /\left(\left(\mathrm{E}_{\mathrm{pt}}+\mathrm{E}_{\mathrm{pt}-5}\right) / 2\right) \\
& =\beta_{1} \mathrm{X}_{\mathrm{pt}-5}+\beta_{2 \mathrm{t}} \mathrm{Ind}_{\mathrm{i}}+\beta_{3 \mathrm{t}} \text { Nonattain }_{\mathrm{ct}-5} \\
& +\beta_{4} 1\left(\text { Emit }^{\mathrm{CO}}=1 \& \text { Nonattain } \mathrm{CO}=1\right)_{\mathrm{cit}-5} \\
& +\beta_{5} 1\left(\text { Emit }_{3}=1 \& \text { Nonattain } \mathrm{O}_{3}=1\right)_{\mathrm{cit}-5} \\
& +\beta_{6} 1\left(\text { Emit } \mathrm{SO}_{2}=1 \& \text { Nonattain } \mathrm{SO}_{2}=1\right)_{\text {cit-5 }} \\
& +\beta_{7} 1(\text { Emit TSPs }=1 \& \text { Nonattain TSPs }=1)_{\mathrm{cit}-5}+\Delta \varepsilon_{\mathrm{pt}}
\end{aligned}
$$

where $\Delta \varepsilon_{\mathrm{pt}}=\alpha_{\mathrm{p}}+\gamma_{\mathrm{ct}}+\Delta \mathrm{u}_{\mathrm{pt}}$. Here $\mathrm{p}$ indexes a plant, $\mathrm{c}$ references county, $\mathrm{i}$ indexes industry, and $\mathrm{t}$ and $\mathrm{t}-5$ index the last and first years of a period, respectively. $\% \Delta \mathrm{E}_{\mathrm{pt}}$ is the dependent variable (i.e., employment, capital stock, the value of shipments) and is measured as the percentage change between t and t-5. ${ }^{19} \Delta \varepsilon_{\mathrm{pt}}$ is the stochastic error term. Equation (1) is weighted by the denominator of the dependent variable to account for differences in cell size,

$\mathrm{X}_{\mathrm{pt}-5}$ is a vector of variables, calculated at t-5 so they are "pre-treatment." There are indicators for: four categories of plant size based on shipments (i.e., smaller than the median, between the median and the 75 th percentile, between the 75 th percentile and the mean, and greater than the mean); whether the plant has operated for at least 10 years; ownership by a firm with multiple establishments; and whether the observation is a response to the Census Bureau questionnaire or is derived from Federal administrative records. Previous research shows that these variables are important determinants of plantlevel growth (Dunne, Roberts, and Samuelson 1989a and 1989b; Davis and Haltiwanger 1992). X $\mathrm{pt}_{\mathrm{pt}-5}$ also contains the average industry-specific wage in the plant's county as a measure of labor costs and the number of employees at other plants within the same county by industry to capture agglomeration effects (Krugman 1991).

$\operatorname{Ind}_{\mathrm{i}}$ is a vector of industry indicator variables, whose effects are allowed to vary by period. In most of the subsequent analysis, there are 13 industry indicators - 1 for each of the 12 industries that are classified as an emitter of at least one of the four regulated pollutants and 1 for the remaining "Clean" industries. These variables non-parametrically absorb all time varying industry-level unobservables at the level that the regulations are applied. Further, the Nonattain $\mathrm{ct}_{\mathrm{c}-5}$ vector contains a separate dummy variable for each of the four pollutant-specific nonattainment designations. These dummies control for

\footnotetext{
${ }^{19}$ This measure of percentage change is an alternative to the difference of the natural logarithms of the year $t$ and $t-5$ levels. It is a second-order approximation to the $\ln$ difference measure, ranges from -2.0 to +2.0 , and portrays expansion and contraction symmetrically (Davis, Haltiwanger, and Schuh 1996). Importantly, it allows the sample to contain observations on "births" and "deaths," that is plants that do not operate in either the first or last year of a period. A comparison of the results from a sample of "stayers" reveals that the estimated regulation effects are nearly identical when the dependent variable is calculated as the ln difference.
} 
unobserved factors that equally affect polluting and non-polluting plants in nonattainment counties. Their effect is also allowed to vary by period.

The parameters $\beta_{4}-\beta_{7}$ capture the variation in the dependent variables specific to polluting plants (relative to non-polluters) in nonattainment counties (relative to attainment ones). These parameters provide estimates of the mean effect of the pollutant-specific regulations on the plants that are directly targeted by them. Henceforth, they are referred to as the "regulation effects." An attractive feature of this specification is that, in contrast to the previous literature, each of the estimated regulation effects is obtained while holding the others constant. ${ }^{20}$ This is relevant because many plants were subject to more than one of the nonattainment designations. ${ }^{21}$

Prior research indicates that there are important permanent and transitory regional determinants of manufacturing activity. ${ }^{22}$ There are a number of ways to model these factors with this data. One possibility is to include county fixed effects so counties that were never designated nonattainment for a particular pollutant are excluded from the estimation of the effect of that pollutant's nonattainment designation. In this case, the pollutant-specific regulation effects are estimated from $189(\mathrm{CO}), 730\left(\mathrm{O}_{3}\right)$, $134\left(\mathrm{SO}_{2}\right)$, and $436(\mathrm{TSPs})$ counties.

As the specification of $\Delta \varepsilon_{\mathrm{pt}}$ indicates, another possibility is to include fixed effects for each of the more than 700,000 plants in the sample and county $\times$ time indicators. The plant fixed effects greatly reduce the degrees of freedom, but they control for differences in permanent plant growth rates that might be correlated with nonattainment status. Such a correlation might occur if nonattainment counties provide the conditions necessary for emitting plants or industries to flourish (e.g., easy access to the interstate highway system or a workforce that suits their technology). In this specification, the regulation

\footnotetext{
${ }^{20} \mathrm{I}$ also experimented with including the 12 "cross-pollutant" interactions (e.g., $1\left(\right.$ Emit $\mathrm{O}_{3}=1 \&$ Nonattain $\mathrm{CO}=1$ ) in the specification. Across the dependent variables and specifications, the hypothesis that they are jointly equal to zero is generally not rejected by a chi-square test at standard confidence levels. Moreover in these plant-level regressions, their inclusion does not substantially alter the estimates of the 4 regulation effects. Notably, the interactions are more important in grouped regressions and with stricter definitions of emitter status, as in Greenstone (1998).

${ }^{21}$ McConnell and Schwab (1990), Henderson (1996), and Becker and Henderson (2000 and 2001) use the equivalent of the $\mathrm{O}_{3}$ nonattainment designation but restrict the effect of the other pollutant-specific designations to equal zero. The remainder of the literature uses regulatory measures that do not allow for the pollutant-specific nature of the CAAAs.

${ }^{22}$ Bartik (1985) and Holmes (1998) show that a number of regional factors including unionization density, tax rates, the provisions of public services, and right-to-work laws affect firms' investment decisions. Moreover, Blanchard and Katz (1992) demonstrate that shocks to regions' growth rates can persist for as long as a decade.
} 
effects are identified from within plant comparisons of growth rates under the nonattainment and attainment regimes.

In summary, the estimated regulation effects are purged of many likely sources of bias. For example, the specification that includes plant fixed effects, county $\times$ time indicators, and industry $\times$ time dummies, is robust to all unobserved permanent determinants of plant growth, all unobserved transitory factors common to polluting and non-polluting plants within a county, and all unobserved industryspecific shocks. However, the estimated regulation effects are not robust to transitory determinants of growth specific to emitting industries (or plants) located in counties that are nonattainment for the emitted pollutant(s). In other words, county $\times$ industry and county $\times$ plant shocks to growth are potential sources of bias.

\section{The Amendments' Impact on Manufacturing Sector Activity}

This section begins by examining an identifying assumption that is common in the previous literature. I then present the estimated effects of the regulations on the growth rates of employment, shipments, and capital from fitting the preferred specifications discussed in the last section. The third subsection tests for heterogeneity in the regulation effects across industries. And the final subsection probes the robustness of the results.

\section{A. Do Location-Specific Unobservables Covary with Nonattainment Status?}

Before turning to the preferred specifications, I explore the validity of the assumption that nonattainment status is orthogonal to location-specific determinants of growth. This identifying assumption is pervasive in the previous literature (e.g., Bartik 1985; Barbera and McConnell 1986; McConnell and Schwab 1990; Henderson 1996; Levinson 1996; Berman and Bui 1998 and 2001; and Becker and Henderson 2000 and 2001). For brevity I focus on the employment dependent variable, but the findings are similar for capital stock and shipments.

Table 4a presents two estimates of the effect of the regulation of each pollutant. The first estimate is derived from a sample that is limited to plants that emit the relevant pollutant and is contained in column (1). The column (2) estimate is obtained from all 1,620,942 plant observations with nonmissing employment growth. In both cases the reported parameter is from an indicator that is equal 
to 1 if the county is nonattainment for the specified pollutant and the plant is an emitter of that pollutant. Additionally, the two specifications include county fixed effects and industry $\times$ time indicators. For the column (1) specification's estimated regulation effect to be unbiased, it is necessary to assume that the regulation of that pollutant is the only county-level determinant of employment growth that differs between nonattainment and attainment counties. In contrast, the column (2) specification controls for unobserved, permanent county-level determinants of growth common to emitters and non-emitters.

A comparison of the columns (1) and (2) estimates provides an informal test of this assumption. The $\mathrm{SO}_{2}$ and TSPs regulation effects are similar in the two columns. However, the $\mathrm{CO}$ and $\mathrm{O}_{3}$ regulation effects in column (1) appear to be biased upwards. Most dramatically, the column (1) $\mathrm{O}_{3}$ estimate suggests that nonattainment status at the beginning of a period is associated with a $6.8 \%$ increase in employment in $\mathrm{O}_{3}$ emitting industries 5 years later. Since pollution can be modeled as an input and regulation as a tax on pollution, standard neoclassical models predict an ambiguous effect on demand for other inputs (e.g., labor). Nevertheless, such a large, positive effect is surprising. In column (2), the estimated $\mathrm{O}_{3}$ regulation effect shrinks to $2.5 \%$, demonstrating the importance of controlling for the growth of non-emitters. It is evident that in the case of $\mathrm{CO}$ and $\mathrm{O}_{3}$, nonattainment status is not orthogonal to county-level determinants of growth. This finding was foreshadowed by Table 3, which documented differences in county and plant-level characteristics between nonattainment and attainment counties.

\section{B. The Effects of the CAAAs on Manufacturing Activity}

\section{Total Employment}

Table $4 \mathrm{~b}$ presents the employment results from the estimation of equation (1), using data from all plant observations over the four periods. Heteroskedastic consistent standard errors are in parentheses (White 1980). Since the data are from censuses, the interpretation of what the standard errors of regression parameters represent is not straightforward. ${ }^{23}$ Importantly, the four regulation effects are estimated simultaneously. The columns correspond to specifications that include additional sets of

\footnotetext{
${ }^{23}$ On the one hand, the sample includes all the members of a finite population so the standard errors of the parameter estimates need not be calculated. On the other hand, the "analytical inference" view states that the observed finite population is a member of an unobserved superpopulation; thus, the standard errors associated with regression parameters have their usual interpretation (Pfefferman and Smith 1985).
} 
controls; the exact controls are noted at the bottom of the table. The mean 5-year growth rate of total employment is $-1.4 \%$.

The column (1) specification includes industry $\times$ period fixed effects and allows the effect of a county's nonattainment status to vary by period. These latter parameters non-parametrically absorb the transitory variation in employment growth common to emitters and non-emitters in nonattainment counties. Here, the estimated regulation effects are derived from comparisons between all attainment and nonattainment counties.

These initial results suggest that nonattainment status modestly retards the growth of employment. The estimates indicate that a $\mathrm{CO}$ nonattainment designation at the beginning of a period is associated with an $8.4 \%$ reduction in employment levels in $\mathrm{CO}$ emitting plants five years later. This estimate would be judged statistically significant at conventional levels. The TSPs regulation effect is $2.4 \%$ and would be considered significant at the $10 \%$ level but not by stricter criteria. In contrast, $\mathrm{O}_{3}$ and $\mathrm{SO}_{2}$ nonattainment status are basically uncorrelated with the respective growth of emitters of those pollutants. Interestingly, the estimated $\mathrm{O}_{3}$ and $\mathrm{SO}_{2}$ regulation effects differ from the estimates that did not account for the effects of the other nonattainment designations as in Table $4 \mathrm{a}$.

Columns (2) and (3) report the results from adding county fixed effects and county $\times$ time effects to the specification, respectively. In both cases, F-tests easily reject the null that the additional parameters are jointly equal to zero. As discussed above, the regulation effects from the column (2) specification are due to comparisons of counties that experience a change in attainment status over the course of the sample. The estimates in column (3) are based on comparisons between emitters and nonemitters within nonattainment counties. In light of the differences in these first three specifications, it is striking that the estimated regulation effects are essentially the same across the columns.

The specification that requires the least restrictive assumptions for unbiasedness of the regulation effects is the one in column (4) that includes separate fixed effects for the approximately 738,000 plants in the data. All permanent differences in plant growth rates are controlled for here. As evidenced by the marked increase in the R-squared statistic (.504 compared to .144), the "fit" of the regression is substantially greater. However, a F-test fails to reject the null that the plant fixed effects are jointly equal to zero. This "over-parameterization" explains the increased standard errors of the four regulation effects. 
The intent in estimating this model is to probe the robustness of the estimated regulation effects from columns (1) - (3). In this specification, two of the regulation effects imply a larger negative effect on employment and two are essentially unchanged relative to the other specifications. In particular, $\mathrm{CO}$ nonattainment status at the beginning of a period is associated with a $16.3 \%$ decline in employment in $\mathrm{CO}$ emitting plants by the end of the period. The magnitude of the $\mathrm{O}_{3}$ regulation effect is larger and the estimate is now -0.049 ; moreover, it would be judged statistically significant at standard levels. The increased magnitude of these two regulation effects suggests that the permanent growth rate of plants that emit $\mathrm{CO}$ and $\mathrm{O}_{3}$ is greater in counties that are nonattainment for these pollutants. This finding is consistent with the notion that these counties offer competitive advantages to emitters of these pollutants. In contrast, the $\mathrm{SO}_{2}$ and TSPs regulation effects are essentially unchanged from the other specifications. ${ }^{24}$

\section{$\underline{\text { Capital Stock }}$}

The last sub-section documents a robust negative correlation between nonattainment status and employment growth. Here, I explore whether nonattainment status is associated with changes in capital stocks. Investment may be particularly sensitive to regulation, because it reflects plants' conjectures about future profitability. Although it is difficult for plants to adjust their capital stock in the short run, the length of time between observations (five years) means that any impact of regulation should be apparent. In particular, it is likely that five years is enough time for establishments to bring new investments "on line," to substantially reduce their capital stock through depreciation ${ }^{25}$, to open new plants, or to cease operations. Interestingly, the previous literature finds that environmental regulations are not a significant deterrent to new investment in plants and equipment. ${ }^{26}$

There are at least three limitations to the CMs data on capital stock. First, the CMs' measure of capital stock is comprised of productive capital and potentially "non-productive" pollution abatement

\footnotetext{
${ }^{24}$ It is thought that one channel through which environmental regulations weaken polluters' competitive position is by causing them to hire additional non-production workers (e.g., engineers or environmental compliance officers) that aid in ensuring adherence with the regulations but do not directly contribute to the production of the firm's output. I examined this hypothesis and find that the regulations' effects were approximately equal across production and non-production workers. In other words, these data do not support this hypothesis.

${ }^{25}$ Dixit and Pindyck (1994) show that the sunk cost nature of many investments combined with uncertainty about the future may make it more profitable for a firm to respond to a large negative shock by allowing its capital stock to depreciate, rather than by ceasing operations.

${ }^{26}$ A review article concludes that, "environmental regulations do not deter investment to any statistically or economically significant degree" (Levinson 1994).
} 
equipment that is mandated by the regulations. This combined measure may cause the estimated regulation effects to be biased upward, relative to the preferred measure of productive investment. ${ }^{27}$ Second, the book value method is used to measure capital stock, which likely overstates the importance of recent investment relative to a perpetual inventory measure. ${ }^{28}$ Third, the capital stock measure does not allow for a test of whether the regulations cause plants to change the rate of new investment and/or affect the value of existing capital. A measure of capital stock that separates new investment from the depreciation/retirement of existing capital would allow for a more nuanced analysis.

The top panel of Table 5 presents estimates of the impact of the nonattainment designations on capital stock accumulation. The mean five-year growth rate of capital stock using the book value method is $36.5 \%$. The columns correspond to specifications that include additional sets of controls as in Table 4B.

Across the specifications, the capital stock estimates suggest that nonattainment status retards investment, but the evidence is less decisive than in the employment regressions. Similar to the employment results, the estimated regulation effects are roughly constant across the first three specifications. The commonality of these estimates is especially apparent in the context of the standard errors. The estimates indicate that the effect of the nonattainment designations on capital stock ranged from small, positive (TSPs) to somewhat large and negative ( $\mathrm{CO}$ and $\left.\mathrm{SO}_{2}\right)$. However, the column (3) $\mathrm{CO}$ regulation effect is the only one that would be judged statistically different than zero.

The addition of plant fixed effects in column (4) greatly increases the R-squared statistic. But the null that these extra parameters are jointly equal to zero is not rejected at conventional significance levels. As in the employment regressions, this specification indicates that the nonattainment designations have a larger negative impact on growth. In particular, the estimated regulation effects from this

${ }^{27}$ The "lumping" of these two types of investment together introduces a positive, mechanical relationship between regulation and observed investment. A preferred measure of capital stock would exclude the investments in pollution abatement equipment that were mandated by the Amendments. The 1986 Pollution Abatement Costs and Expenditures survey provides some indirect evidence on the magnitude of this bias. It shows that the heaviest polluting industries devote approximately $4 \%-10 \%$ of total investment to abatement equipment. This share is likely to be larger in nonattainment counties and indicates that the upward bias may not be insignificant. See Becker (2001).

${ }^{28}$ A book value system permanently records the value of an investment at its purchase price. This value is never updated to reflect inflation or changes in the good's market value. Therefore, the relative contribution of recent investment, which is entered in current dollars, is overstated. A perpetual inventory measure of capital stock accounts for these changes but is not feasible with the CM questionnaire. 
specification are -0.092 for $\mathrm{CO},-0.041$ for $\mathrm{O}_{3},-0.063$ for $\mathrm{SO}_{2}$, and -0.043 for TSPs. The loss of the approximately 700,000 additional degrees of freedom causes three of the four standard errors to increase so that the null hypothesis of zero is not rejected for any one of them.

\section{$\underline{\text { Shipments }}$}

In a standard neoclassical model where pollution, labor, and capital are inputs in the production process, the predicted effect of regulation, which increases the "cost" of pollution, on labor and capital demand is ambiguous. However, the theoretical prediction on output is unambiguously negative. Consequently, the shipments results provide a more direct test of whether nonattainment status affects polluters.

The bottom panel of Table 5 reports estimation results for the growth in constant dollar shipments. The mean five-year growth rate is $10.0 \% .{ }^{29}$ In columns (1) - (3), the CO regulation effect is negative and statistically distinguishable from zero in two of the three specifications. These estimates indicate that $\mathrm{CO}$ nonattainment status is associated with a $3.6 \%-7.2 \%$ decrease in shipments by $\mathrm{CO}$ emitters. The $\mathrm{O}_{3}$ regulation effect is small and positive, while the $\mathrm{SO}_{2}$ and TSPs regulation effects are small and negative.

As with the employment and capital stock regressions, controlling for plant fixed effects in column (4) causes the estimated negative effects of nonattainment status to be of a greater magnitude. In this specification, the estimated regulation effects are -0.146 for $\mathrm{CO},-0.032$ for $\mathrm{O}_{3},-0.010$ for $\mathrm{SO}_{2}$, and 0.032 for TSPs. Again the interpretation of the standard errors is not obvious, but the CO regulation effect is the only that is statistically significant at conventional levels. Overall, these results imply that nonattainment status, particularly $\mathrm{CO}$ nonattainment status, is associated with a reduction in shipments by polluting manufacturers.

\section{A Comparison of the Estimates Across the Dependent Variables}

A comparison of the estimates across the three dependent variables within and across specifications provides a crude view into the "black box" of how firms respond to environmental

\footnotetext{
${ }^{29}$ The Bartelsman and Gray (1994) NBER Productivity Database four digit industry deflators are used to express the total value of shipments in 1987 dollars.
} 
regulations. For example, consider the $\mathrm{CO}$ regulation effects. In the columns (1) - (3) specifications, the regulation effects range from -0.075 to -0.086 for employment, -0.047 to -0.097 for capital stock, and 0.036 to -0.072 for shipments. The estimates from the column (4) specification are $-0.163,-0.092$, and 0.146 , respectively. Within these two divisions of the specifications, the estimates are approximately equivalent across the dependent variables, particularly in the context of the associated standard errors. The same pattern is evident in the effects of the other nonattainment designations, although they are not as large either economically or statistically. Overall the estimates suggest that the regulations cause employment, capital stock, and shipments to decline by roughly equivalent proportions. ${ }^{30}$

\section{Is there Heterogeneity in the Regulation Effects Across Industries?}

This sub-section explores whether the regulation effects vary by industry. This is informative for at least two reasons. First, it serves as an internal validity check on the above results. If the entire regulation effects are concentrated in a small subset of emitting industries, it may be reasonable to presume that the estimated regulation effects are due to an unobserved factor that is unrelated to regulation. As an example, union activism might differ over time and the union activity in a particular industry might be more heavily concentrated in nonattainment counties. Further such an unobserved factor could interact with the dramatic reductions in demand experience by some industries during the examined period; for instance, employment of production workers in Primary Metal Industries (SIC Code 33) declined from $1,059,000$ in 1967 to only 538,000 in 1987. Second, it provides an opportunity to measure the effects of these regulations across industries. This might prove useful in evaluating the claims that particular industries are especially harmed by the CAAAs.

Table 6 presents the industry-specific regulation effects from the estimation of equation (1) for employment. The results are qualitatively similar for capital stock and shipments but are not presented here due to space considerations. The estimated specification includes plant fixed effects, county $\times$ time effects, and industry $\times$ time effects, as in column (4) of Table $4 \mathrm{~b}$. The regulation effects are allowed to vary across the industries that emit the relevant pollutant so there are a total of 23 estimated regulation effects. Columns (1)-(12) report the industry-specific regulation effects and heteroskedastic consistent

\footnotetext{
${ }^{30}$ It would be informative to have plant-level data on pollution emissions. This data would allow for the calculation of the marginal rate of technical substitution between pollution and labor or capital. These measures of the ease of substitution are important policy parameters and are left for future research.
} 
standard errors (in parentheses), where each column pertains to an industry. By reading across a row, it is possible to compare the pollutant-specific regulation effects in each of the relevant industries. Column (13) lists the chi-square statistic and associated p-value (in parentheses) from tests that the pollutantspecific regulation effects are equal across industries.

A number of points emerge from the table. First, it is apparent that the estimation of industryspecific regulation effects demands a lot from the data, as the standard errors are substantially larger than they were in Table 4b. The decrease in precision is partially due to the fact that a number of the plants that emitted multiple pollutants were located in counties that were nonattainment for multiple pollutants (recall Figures 1a-1d), which make it difficult to separately identify them. Interestingly, the positive estimates tend to be especially poorly determined.

Second, the four chi-square tests fail to reject the null hypothesis that the pollutant-specific regulation effects are equal across industries. This is certainly related to the imprecision of the estimates, but an "eye-ball" test does reveal striking similarities in the parameters within a row (see especially the $\mathrm{CO}$ and TSPs effects). I conclude that the estimated regulation effects in Table $4 \mathrm{~b}$ do not reflect the experiences of a small subset of emitting industries.

Third, almost all of the emitting industries are negatively impacted by the nonattainment designations. Only 5 of the 23 estimated industry-specific regulation effects are greater than zero. Of these 5, 4 occur in industries that emit other pollutants for which the associated regulation effect is negative; thus, the overall effect of the CAAAs on these industries may still be negative.

Fourth, the total effect of the regulations is particularly harsh on industries that emit multiple pollutants in counties that are nonattainment for those pollutants. For example, a literal interpretation of the coefficients suggests that Pulp and Paper plants located in counties that are nonattainment for all four pollutants at the beginning of a period experience an employment decline of almost $29 \%$ over 5 years. Similar calculations suggest that employment declines by $14.1 \%$ in a period at Petroleum Refining plants in counties that are nonattainment for $\mathrm{CO}, \mathrm{O}_{3}$, and $\mathrm{SO}_{2}$.

\section{Robustness Checks}

This paper has used variation in regulation across counties, industries, and time in an effort to estimate the causal effect of regulation on industrial activity. However as is always the case with a non- 
experimental design, there is a form of unobserved heterogeneity that can explain the findings without a causal interpretation. In addition to the efforts presented above, I probed the robustness of the estimates in a number of other ways but found little evidence that undermines the basic conclusions.

Table 7 reports the results of some of these robustness checks in columns (1) - (3). The entries are the estimated regulation effects and heteroskedastic standard errors (in parentheses) from separate regressions for the three dependent variables. The dependent variable is denoted in bold and underlined. Each column represents a different specification or sample. All specifications include county $\times$ period fixed effects and industry $\times$ period effects. The results are qualitatively similar when the specification with plant fixed effects is estimated, but the standard errors increase substantially because two of the robustness checks significantly cut the sample size. The entries in column (0) are taken from column (3) of Tables $4 \mathrm{~b}$ (employment) and 5 (capital stock and shipments) and should be compared to the entries in the other columns.

One potential source of bias arises from the manner in which nonattainment status is determined and dynamics in the growth of manufacturing activity. Recall that a county's nonattainment designations are determined by its pollution concentrations, which are increasing in manufacturing activity. Thus, nonattainment status in the first year of a period is likely an increasing function of previous growth. This may induce a mechanical correlation between the regulation variables and the unobserved components of the dependent variable in equation (1) if manufacturing growth follows a dynamic process. When the process is mean reverting, this correlation is likely to bias the estimated regulation effects downwards. ${ }^{31}$

To determine whether the above results are due to dynamics, column (1) presents results from the estimation of an equation that includes the lagged value of the dependent variable (i.e., the percentage change between $\mathrm{t}-5$ and $\mathrm{t}-10$ ) and interactions of the lag with the four pollutant emitted indicators as controls. The parameters from the lagged dependent variables are not reported in the table but provide evidence of dynamic patterns of growth in manufacturing activity. The commonality of the estimates in columns (0) and (1) imply that the regulation effects are not due to mean reversion. ${ }^{32}$

\footnotetext{
${ }^{31}$ To understand the direction of bias, consider the case where there is "above-average" growth among emitters of a pollutant in a county in the period between $t-5$ and t- 10 . This growth might cause the county to be designated nonattainment in $\mathrm{t}-5$. If the dependent variable follows a mean reverting process, these polluters are likely to have smaller growth in the period between $t$ and $t-5$. This slower growth would have occurred even in the absence of regulation, yet the regression would attribute this decline to regulation.

${ }^{32}$ The estimates are virtually identical when the column (0) sample is limited to plants with nonmissing lagged
} 
It is generally assumed that environmental regulations' primary impact is on the location decisions of new plants (e.g., Bartik 1985; McConnell and Schwab 1990) and that through "grandfather" clauses and political lobbying incumbent plants are able to escape regulation. In column (2) of Table 7, the sample is limited to "stayers," that is plants that are operating in both the first and last years of a period. The estimated regulation effects in this column are remarkably similar to those from the base specification, indicating that the regulations also restrict the growth of "stayers." The negative coefficients from the capital stock regression are noteworthy, because the required installation of "end of the line" pollution abatement equipment that increases measured investment (but not productive investment) is thought to be especially prevalent among "stayers.",33

I also examine the sensitivity of the estimated regulation effects to the definitions of emitting status. For example, column (3) of Table 7 presents the results from regressions where the group of emitters is expanded such that industries that account for more than $4.5 \%$ of the industrial sector's emissions are classified as an emitter of that pollutant (see Appendix Table 2). The estimated regulation effects are generally unchanged by this expansion of the list of emitters. Further, I tested whether the effects differed when an industry had to account for $9 \%$ of industrial sector emissions to quality as a polluter. The estimated regulation effects are also qualitatively similar in this case. ${ }^{34}$

Another possible source of bias is that plants located in a county that is currently nonattainment but is "expected" to become attainment in the near future might delay investments until the regulation designation is changed. In the presence of this type of temporal shifting, the estimated regulation effects would be negative but over longer periods regulation would have no effect on manufacturing activity. In order to explore this possibility, I restricted the sample so that plant observations from counties that are nonattainment for a particular pollutant in that period but attainment for the same pollutant in the next period are dropped. This sample restriction is implemented 4 separate times, once for each of the pollutant-specific nonattainment designations. The estimated regulation effects from these restricted samples are statistically indistinguishable to those from the full sample. These results indicate that it is unlikely that this form of temporal shifting of investment is the source of the estimated regulation effects.

A further potential source of bias comes from unobserved regional shocks to industries. I

\footnotetext{
dependent variables.

${ }^{33}$ Greenstone (1998) provides evidence on the regulations' effect on plant location and exit decisions.

${ }^{34}$ These results and the other results discussed in the remainder of the subsection are available from the author.
} 
estimated a model that controlled for unrestricted industry $\times$ period $\times$ region effects, where industry is defined as one of the 13 "industries" described above and regions are the nine Census Bureau regions of the U.S. The estimated regulation effects from this specification are also similar to those presented in Tables $4 \mathrm{~b}$ and 5. Additionally, I fit a model that allows the industry shocks to vary at the state level, rather than the Census region level. In a further specification, I disaggregated industry and estimated an equation that includes SIC 3 digit industry $\times$ period $\times$ region effects. Neither of these alternatives substantially changes the estimated regulation effects. Overall, there is little evidence that the regulation effects are due to regional industry shocks.

Finally, due to the coincidence of the implementation of these regulations and the decline in manufacturing activity in "Rust Belt" states, it is sometimes thought that the regulations caused this decline (e.g., Kahn 1999). ${ }^{35}$ To examine this possibility, I separately estimated the regulation effects on samples from the Rust Belt and non-Rust Belt states. Across the three measures of manufacturing activity, the estimates indicate that the regulations retard the growth of polluting manufacturers in both sets of states.

\section{The Magnitude of the Regulation Effects and their Interpretation}

The above analysis indicates that the CAAAs reduced the relative growth of pollution intensive manufacturing activity in nonattainment counties. This section provides answers to three important questions about the estimated regulation effects. How large are they? Can they be used to assess claims that the CAAAs cause manufacturers to shift production (and jobs) abroad? Further, do they provide estimates of the costs of the CAAAs that can be compared to estimates of its benefits?

\section{A. The Magnitude of the Regulation Effects}

Table 8 develops two measures of the magnitude of the regulation effects. Notice that there are three panels, one for each of the measures of manufacturing activity. The first column presents the estimated regulation-induced change in the measures of activity. This is calculated by multiplying the sum of the activity in affected plants (recall, Table 2) by the relevant estimated regulation effects from the specification that includes plant fixed effects (i.e., column (4) of Tables $4 \mathrm{~b}$ and 5). They are

\footnotetext{
${ }^{35}$ The Rust Belt is defined to include Illinois, Indiana, Michigan, New York, Ohio, and Pennsylvania.
} 
presented separately for each regulation effect and the sum of the regulation-induced changes is in the “All Manufacturers" row. Column (2) lists the 95\% confidence interval of these estimates. Column (3) reports the change in the measure of activity between the period when the CAAAs were first in force and the last period (i.e., 1972-77 and 1982-87), separately for emitters of each of the pollutants and the entire manufacturing sector. Finally, column (4) lists the mean of the levels from these two periods for the same categories of plants.

The entries in columns (1), (3), and (4) are used to calculate the two measures of the magnitude of the regulation effects. Column (5) reports the ratio of the entries in columns (1) and (3) and column (6) lists the ratio of columns (1) and (4). Thus, these columns normalize the regulation-induced changes by the total change in and mean of the measures of activity.

The top panel reports these calculations for employment. For example, employment in $\mathrm{CO}$ emitting industries located in CO nonattainment counties declined by 119,100 jobs (relative to CO emitters in $\mathrm{CO}$ attainment counties) in the first 15 years that the CAAAs were in force. ${ }^{36}$ The $95 \%$ confidence interval of this estimate is $[-54,600,-183,500]$. Analogous calculations indicate that the cumulative regulation induced change [95\% confidence interval] in employment in nonattainment counties is $-423,400[-169,400,-677,400]$ for $\mathrm{O}_{3}, 800[57,400,-55,800]$ for $\mathrm{SO}_{2}$, and $-50,200[48,200$, 148,500] for TSPs. The large decline in $\mathrm{O}_{3}$ employment reflects the high levels of employment in $\mathrm{O}_{3}$ emitting industries. The sum of the regulation-induced changes is 591,900 [-118,400, -1,065,200].

The first measure of the magnitude indicates that the total regulation-induced change is almost 2.4 times as large as the decline in manufacturing sector employment (roughly 250,000 jobs). This ratio appears large, but it primarily reflects that manufacturing sector employment was flat. The second measure reveals that the regulation-induced change in nonattainment counties was a more modest $3.4 \%$ of total manufacturing sector employment.

The second and third panels present the analogous calculations for capital stock and shipments, respectively. The cumulative regulation-induced changes in capital stock and shipments across all four regulations are $\$ 36.6$ billion [ $\$ 16.4$ billion, $-\$ 89.6$ billion] and $\$ 75.5$ billion (1987\$) [\$27.4 billion, $\$ 178.0$ billion], respectively. These changes are $8.9 \%$ and $33.1 \%$ of the total change in these measures of

\footnotetext{
${ }^{36}$ This is calculated by multiplying the estimated effect of $\mathrm{CO}$ nonattainment status $(-0.163)$ by the sum of the levels of employment in CO emitting plants located in nonattainment counties for 1972-1977 (201,108), 1977-1982 $(302,989)$, and 1982-1987 (226,294).
} 
manufacturing activity. When they are normalized by the mean levels of capital stock and shipments, they are $6.5 \%$ and $3.7 \%$, respectively.

Overall these two measures indicate that during the first 15 years that the CAAAs were in force, the cumulative regulation-induced changes in manufacturing activity in nonattainment counties were not insignificant relative to either changes in or the level of total manufacturing sector activity. It is important to bear in mind, however, that the legislation also specified regulations for attainment counties. Consequently, it is likely that the effects of the CAAAs would be larger if the comparison were to counties that were not subject to any regulation.

\section{B. Interpretation}

It would be informative if the estimated regulation effects could be used to determine how much production (and employment) was shifted abroad due to the CAAAs. ${ }^{37}$ This would provide one measure of the national costs of these regulations. Unfortunately, such a calculation is not possible because it cannot be determined whether the lost activity in nonattainment counties moved to foreign countries or attainment counties. Since it is likely that the regulation effects partially reflect some shifting of manufacturing activity within the U.S., they probably overstate the national loss of activity. Moreover, the possibility of intra-country shifting means that the regulation effects are also likely to overstate losses in nonattainment counties. This is because the identification strategy relies on comparisons between nonattainment and attainment counties, which leads to double counting when production is moved from a nonattainment county to an attainment one. ${ }^{38}$

There are at least two reasons to doubt that the regulation effects entirely reflect a movement of plants from nonattainment to attainment counties. First, counties frequently moved into and out of nonattainment status. Thus firms may have found it unreasonable to assume that they could remain in the U.S. and escape future regulation. Second, production in many of the regulated industries (e.g., iron and

\footnotetext{
${ }^{37}$ A related question is whether environmental regulations alter the international location decisions of polluters. An extrapolation of this paper's findings to this question suggests that international differences in the stringency of environmental regulation will tend to shift polluters' production to countries with relatively lax environmental standards.

${ }^{38}$ In the extreme, the estimated regulation effects entirely reflect a movement of manufacturing activity from nonattainment to attainment counties. In this scenario there would be no loss of production (and jobs) to foreign countries. Further, the regulation effects would overstate the lost production in nonattainment counties by a factor of two.
} 
steel and pulp and paper) requires substantial "sunk" costs that make it costly to shift locations.

The estimated regulation effects have an additional limitation as a measure of the costs of regulation. They are calculated in terms of employment, investment, and shipments but these measures are not readily comparable to standard measures of the benefits of regulation. The conversion of these measures into a monetary unit would have great practical importance. For instance, it would then be possible to compare the costs of the regulations with hedonic housing market estimates of the monetary gains to homeowners from regulation-induced pollution reductions.

A full monetizing of the regulation-induced losses is left to future research, but it is worth noting that this task is tractable. In a freely functioning market economy, jobs and capital are not lost or made obsolete. In response to a shock like the imposition of environmental regulations, these factors of production generally become employed in another capacity. Thus, the losses due to regulation are the adjustment costs associated with the shifting of resources to new sectors. It is evident that monetized estimates of the costs of the CAAAs require reliable estimates of the magnitude of these frictions.

I close this section by noting that recent research indicates that these frictions may be quite substantial and can persist for as long as a decade (Blanchard and Katz 1992). Jacobson, LaLonde, and Sullivan (1993) document that displaced workers endure substantial wage losses. Consequently, people who lost their jobs due to environmental regulations may have suffered substantial long-run wage declines.

\section{Conclusions}

This paper provides new evidence that environmental regulations retard industrial activity. I find that in the first 15 years after the CAAAs became law (1972-1987), nonattainment counties (relative to attainment ones) lost approximately 590,000 jobs, $\$ 37$ billion in capital stock, and $\$ 75$ billion (1987\$) of output in polluting industries. Although these estimates are not derived from a randomized experiment and therefore cannot meet a strict definition of causality, they provide robust evidence that these regulations deter the growth of polluters. In the first place, the findings are derived from the most comprehensive data available on clean air regulations and manufacturing activity. Second, the preferred statistical model for plant level growth controls for all permanent plant characteristics, unrestricted industry shocks, and unrestricted county shocks. Third, the effects are robust across a variety of 
specifications. Finally, the regulation effects are evident across three different measures of manufacturing activity and a wide range of polluting industries.

The ozone and particulates standards were tightened recently, causing a substantial increase in the number of nonattainment counties. ${ }^{39}$ The balance of evidence from this paper suggests that the new nonattainment counties will experience reductions in employment, investment, and shipments in polluting industries. To gain a clearer understanding of whether it is worthwhile to incur the costs associated with these reductions, it is crucial to understand the regulations' effectiveness at cleaning the air and the benefits of cleaner air. Recent research finds that these policies are effective at reducing air pollution concentrations and that cleaner air, particularly reductions in TSPs, provides substantial monetary benefits to homeowners and reduced infant mortality rates (Smith and Huang 1995; Henderson 1996; Chay and Greenstone 2000, 2001a, and 2001b). Regardless of whether these policies pass or fail a cost-benefit test, this paper's findings undermine the contention that environmental regulations are costless or even beneficial for the regulated.

\footnotetext{
${ }^{39}$ Although legal wrangling over this policy change is not concluded, the Supreme Court's Whitman v. American
} Trucking Associations decision appears to uphold the EPA's decision to tighten these standards. 


\section{Data Appendix}

\section{a. Determining the County-Level, Pollutant-Specific Regulation Designations}

The centerpiece of the Clean Air Act Amendments is the annual, county-level assignment of nonattainment and attainment status for $\mathrm{CO}, \mathrm{O}_{3}, \mathrm{SO}_{2}$, and TSPs. This section describes how these designations are determined for each of the four periods (i.e., 1967-1972, 1972-1977, 1977-1982, 19821987) examined in this paper.

Although the 1970 Amendment passed before the 1967-1972 period ended, the associated enforcement activities did not commence until late 1971 (Liroff 1986). Consequently, all counties are designated attainment for the four pollutants in the 1967-1972 period.

The determination of the nonattainment statuses in the 1977-1982 and 1982-1987 periods is relatively straightforward. In 1978 the EPA began to publish annually a list of nonattainment counties in the Code of Federal Regulations $(C F R){ }^{40}$ For each of the regulated pollutants, the CFR lists every county as, "does not meet primary standards," "does not meet secondary standards," "cannot be classified," "better than national standards," or "cannot be classified or better than national standards." Further, the CFR occasionally indicates that a part of a county did not meet the primary standards. For the 1977-1982 (1982-1987) period, a county to the pollutant-specific nonattainment category if all or part of it failed to meet the pollutant-specific "primary standards" in 1978 (1982); otherwise, it is assigned to the pollutant-specific attainment category. These annual, county-level, pollutant-specific designations were hand entered for the 3,070 U.S. counties.

The determination of the identities of the nonattainment counties in the 1972-77 period is more complicated. The EPA did not publicly announce them in the early years of regulation and I was told that records from that period "no longer exist." Consequently, I filed a freedom of information act request and obtained the EPA's "Quick Look Report" data file, which contains annual summary information on the readings from each EPA pollution monitor. ${ }^{41}$ This file is used to replicate the EPA's regulation rule; counties, with monitor readings exceeding the pollutant-specific national standard in 1972 are assigned to the pollutant-specific nonattainment category for the 1972-1977 period. All other county by pollutant combinations are designated attainment. ${ }^{42}$

\section{b. Determining Which Plants were Subject to the Regulations}

An important part of the analysis is the determination of which manufacturing plants (or industries) were not targeted by the regulations in the examined period. A historical list of regulated plants or industries is unavailable from the EPA. Consequently, I devised a system to divide the manufacturing sector into emitters and non-emitters that attempts to mimic the EPA's focus on the dirtiest plants and industries in the initial years of regulation.

The EPA's estimates of industrial emissions are used to determine the pollutants emitted by each industry. These estimates are reproduced in Appendix Table 2. The table lists the estimated annual emissions of each of the regulated pollutants by industry, as well as each industry's share of total industrial sector emissions. Industries that are excluded from the table either produce negligible levels of the regulated pollutants or had escaped the EPA's attention as late as the early 1990s. Communications with EPA officials indicate that it is unlikely that the excluded industries were subject to significant regulatory oversight in the 1970s and 1980s.

\footnotetext{
${ }^{40}$ Vernon Henderson and Randy Becker generously allowed me to photocopy the relevant sections of the Code of Federal Regulations.

${ }^{41}$ This date file comes from the EPA's Air Quality Subsystem database and contains annual statistics on the readings from all state and national pollution monitors for the four criteria pollutants.

${ }^{42}$ I tested whether the results were sensitive to the choice of a pollution monitor-based definition of which county/pollutant combinations were heavily regulated for this period (i.e., 1972-1977). The paper's conclusions are insensitive to dropping the 1972-1977 period from the sample.
} 
In assigning polluter status to industries, one possibility is to assume that the industries listed in Appendix Table 2 are regulated for all of the pollutants. Since some industries are major polluters of a particular pollutant, but not of another, it is evident that this is not a sensible approach. Consequently, I label all industries that account for at least $7 \%$ of the industrial sector emissions of a pollutant to be an emitter of that pollutant; excluded industries and those whose emissions fall below the pollutant-specific $7 \%$ threshold are non-polluters. The results are insensitive to other "reasonable" definitions of emitter status. 


\section{References}

Barbera, Anthony J. and Virginia D. McConnell. 1986. "Effects of Pollution Control on Industry Productivity: A Factor Demand Approach.” The Journal of Industrial Economics (35): 161-172.

Bartelsman, Eric and Wayne Gray. 1994. NBER Manufacturing Productivity Database, available at http://www.nber.org/pub/productivity.

Bartik, Timothy J. 1985. "Business Location Decisions in the United States: Estimates of the Effects of Unionization, Taxes, and Other Characteristics of States." Journal of Business and Economic Statistics. 3: 14-22.

Becker, Randy. 2001. "Air Pollution Abatement Costs and the Clean Air Act: Evidence from the PACE Survey." Mimeograph. U.S. Bureau of the Census.

Becker, Randy and Vernon Henderson. 2000. "Effects of Air Quality Regulations on Polluting Industries." Journal of Political Economy. 108: 379-421.

Becker, Randy and Vernon Henderson. 2001. "Costs of Air Quality Regulation," in Behavioral and Distributional Effects of Environmental Policy, edited by Carlo Carraro and Gilbert E. Metcalf. Chicago: The University of Chicago Press.

Berman, Eli and Linda T. M. Bui. 1998. "Environmental Regulation and Productivity: Evidence from Oil Refineries.” Working Paper no. 6766. Cambridge, MA: NBER.

Berman, Eli and Linda T. M. Bui. 2001. "Environmental Regulation and Labor Demand: Evidence from the South Coast." Journal of Public Economics. 79(2): 265-295.

Blanchard, Olivier Jean, and Lawrence F. Katz. 1992. "Regional Evolutions." Brookings Papers on Economic Activity. 1: 1-75.

Bovenberg, A. Lans and Frederick van der Ploeg. 1996. "Optimal Taxation, Public Goods and Environmental Policy with Involuntary Unemployment." Journal of Public Economics. 62: 5983.

Chay, Kenneth and Michael Greenstone. 2000. "Does Air Quality Matter? Evidence from the Housing Market." Mimeograph, University of Chicago.

Chay, Kenneth and Michael Greenstone. 2001a. "The Impact of Air Pollution on Infant Mortality: Evidence from Geographic Variation in Pollution Shocks Induced by a Recession." Mimeograph, University of Chicago.

Chay, Kenneth and Michael Greenstone. 2001b. "Air Quality, Infant Mortality, and the Clean Air Act of 1970." Mimeograph, University of Chicago.

Cleveland, W.S. and T.W. Graedel. 1979. "Photochemical Air Pollution in the Northeast Unites States." Science 204: 1273-78.

Cleveland, W.S., B. Keiner, J.E. McRae, J.L. Warner. 1976. "Photochemical Air Pollution: Transport from the New York City Area into Connecticut and Massachusetts." Science 191: 179-181.

Cohen, Mark A. 1998. "Monitoring and Enforcement of Environmental Policy." Unpublished Paper, Vanderbilt University, Owen Graduate School of Management.

Davis, Steven J., and John Haltiwanger. 1992. "Gross Job Creation, Gross Job Destruction, and Employment Reallocation.” Quarterly Journal of Economics. 107: 819-864.

Davis, Steven J., John C. Haltiwanger, and Scott Schuh. 1996. Job Creation and Destruction, MIT Press: Washington, DC.

Dixit, Avinash K. and Robert S. Pindyck. 1994. Investment Under Uncertainty, Princeton University Press: Princeton, NJ.

Dockery, Douglas W., et al. 1993. "An Association Between Air Pollution and Mortality in Six U.S. Cities." The New England Journal of Medicine, 329(24): 1753-9.

Dunne, Timothy, Mark J. Roberts, and Larry Samuelson. 1989a. "Plant Turnover and Gross Employment Flows in the U.S. Manufacturing Sector." Journal of Labor Economics. 7: 48-71. . 1989b. "The Growth and Failure of U.S. Manufacturing Plants." Quarterly Journal of 
Economics. 104: 671-698.

Environmental Protection Agency. 1995. Sector Notebook Project (various volumes), Office of Compliance: Washington, DC.

Gray, Wayne B., and Ronald J. Shadbegian. 1995. "Pollution Abatement Costs, Regulation, and PlantLevel Productivity.” Working Paper no. 4994. Cambridge, MA: NBER.

Greenstone, Michael. 1998. "The Impacts of Environmental Regulations on Industrial Activity: Evidence from the 1970 and 1977 Clean Air Act Amendments and Census of Manufactures." Princeton University Industrial Relations Section Working Paper, No. 408. Princeton, NJ. . 2000. "The Impact of the Clean Air Act Amendments on Sulfur Dioxide Concentrations." Mimeograph, University of Chicago.

Henderson, J. Vernon. 1996. "Effects of Air Quality Regulation." American Economic Review. 86: 789-813.

Holmes, Thomas J. 1998. "The Effect of State Policies on the Location of Manufacturing: Evidence from State Borders." Journal of Political Economy. 106: 667-705.

Jaffe, Adam B., Steven R. Peterson, Paul R. Portney, and Robert N. Stavins. 1995. "Environmental Regulation and the Competitiveness of U.S. Manufacturing." Journal of Economic Literature. 33: 132-163.

Jacobson, Louis S., Robert J. LaLonde, and Daniel G. Sullivan. 1993. "Earnings Losses of Displaced Workers." American Economic Review. 83: 685-709.

Kahn, Matthew E. 1999. "The Silver Lining of Rust Belt Manufacturing Decline." Journal of Urban Economics. 46: 360-76.

Krugman, Paul. 1991. Geography and Trade, MIT Press: Cambridge, MA.

Lave, Lester B. and Gibert S. Omenn. 1981. Clearing the Air: Reforming the Clean Air Act, The Brookings Institution: Washington, DC.

Levinson, Arik. 1994. "Environmental Regulations and Industry Location: International and Domestic Evidence." Mimeo, University of Wisconsin, Department of Economics.

Levinson, Arik. 1996. "Environmental Regulations and Manufacturers' Location Choices: Evidence from the Census of Manufactures." Journal of Public Economics. 62: 5-29.

Liroff, Richard A. 1986. Reforming Air Pollution Regulations: The Toil and Trouble of EPA's Bubble, The Conservation Foundation: Washington, D.C.

McConnell, Virginia D. and Robert M. Schwab. 1990. "The Impact of Environmental Regulation on Industry Location Decisions: The Motor Vehicle Industry." Land Economics. 66:67-81.

Nadeau, Louis W. 1997. "EPA Effectiveness at Reducing the Duration of Plant-Level Noncompliance." Journal of Environmental Economics and Management. 34: 54-78.

Pfefferman, D., and T.M.F. Smith, 1985. "Regression Models for Grouped Populations in Cross-Section Surveys." International Statistical Review. 53: 37-59.

Porter, Michael E., and Claas van der Linde. 1995. "Toward a New Conception of the EnvironmentCompetitiveness Relationship." Journal of Economic Perspectives. 9: 97-118.

Ransom, Michael R. and C. Arden Pope III. 1995. "External Health Costs of a Steel Mill." Contemporary Economic Policy. 8: 86-97.

Smith, V. Kerry and Ju-Chin Huang. 1995. "Can Markets Value Air Quality? A Meta-Analysis of Hedonic Property Value Models.” Journal of Political Economy. 103: 209-227.

US Bureau of the Census. various years. Pollution Abatement Costs and Expenditures, MA-200 ( )-1, US Government Printing Office: Washington, DC.

Vesilind, P. Aarne, J. Jeffrey Peirce, and Ruth Weiner. 1988. Environmental Engineering, Butterworth-Heinemann: Boston

White, Halbert. 1980. "A Heteroskedasticity-Consistent Covariance Matrix Estimator and A Direct Test for Heteroskedasticity." Econometrica. 48(4): 817-838. 
Table 1: Incidence and Changes in Nonattainment Status

\begin{tabular}{|c|c|c|c|}
\hline & $\begin{array}{l}\text { Nonattainment Period } \mathrm{t} \\
(1) \\
\end{array}$ & $\begin{array}{c}\text { Attainment Period } \mathrm{t}-1 \\
\& \text { Nonattainment Period } \mathrm{t} \\
(2)\end{array}$ & $\begin{array}{l}\text { Nonattainment Period } \mathrm{t}-1 \\
\& \text { Attainment Period } \mathrm{t} \\
\text { (3) }\end{array}$ \\
\hline \multicolumn{4}{|c|}{ Carbon Monoxide (CO) } \\
\hline 1967-1972 & 0 & 0 & 0 \\
\hline 1972-1977 & 81 & 81 & 0 \\
\hline 1977-1982 & 144 & 90 & 27 \\
\hline 1982-1987 & 137 & 15 & 22 \\
\hline \multicolumn{4}{|l|}{ Ozone $\left(\mathrm{O}_{3}\right)$} \\
\hline $1967-1972$ & 0 & 0 & 0 \\
\hline 1972-1977 & 32 & 32 & 0 \\
\hline 1977-1982 & 626 & 595 & 1 \\
\hline 1982-1987 & 560 & 104 & 170 \\
\hline \multicolumn{4}{|c|}{ Sulfur Dioxide $\left(\mathrm{SO}_{2}\right)$} \\
\hline 1967-1972 & 0 & 0 & 0 \\
\hline $1972-1977$ & 34 & 34 & 0 \\
\hline 1977-1982 & 87 & 75 & 22 \\
\hline 1982-1987 & 60 & 7 & 34 \\
\hline \multicolumn{4}{|c|}{ Total Suspended Particulates (TSPs) } \\
\hline $1967-1972$ & 0 & 0 & 0 \\
\hline $1972-1977$ & 296 & 296 & 0 \\
\hline 1977-1982 & 235 & 108 & 169 \\
\hline $1982-1987$ & 176 & 24 & 83 \\
\hline
\end{tabular}

Notes: There are 3,070 counties in the CM data files. See the Data Appendix for a description of how the pollutant-specific nonattainment designations are assigned. 


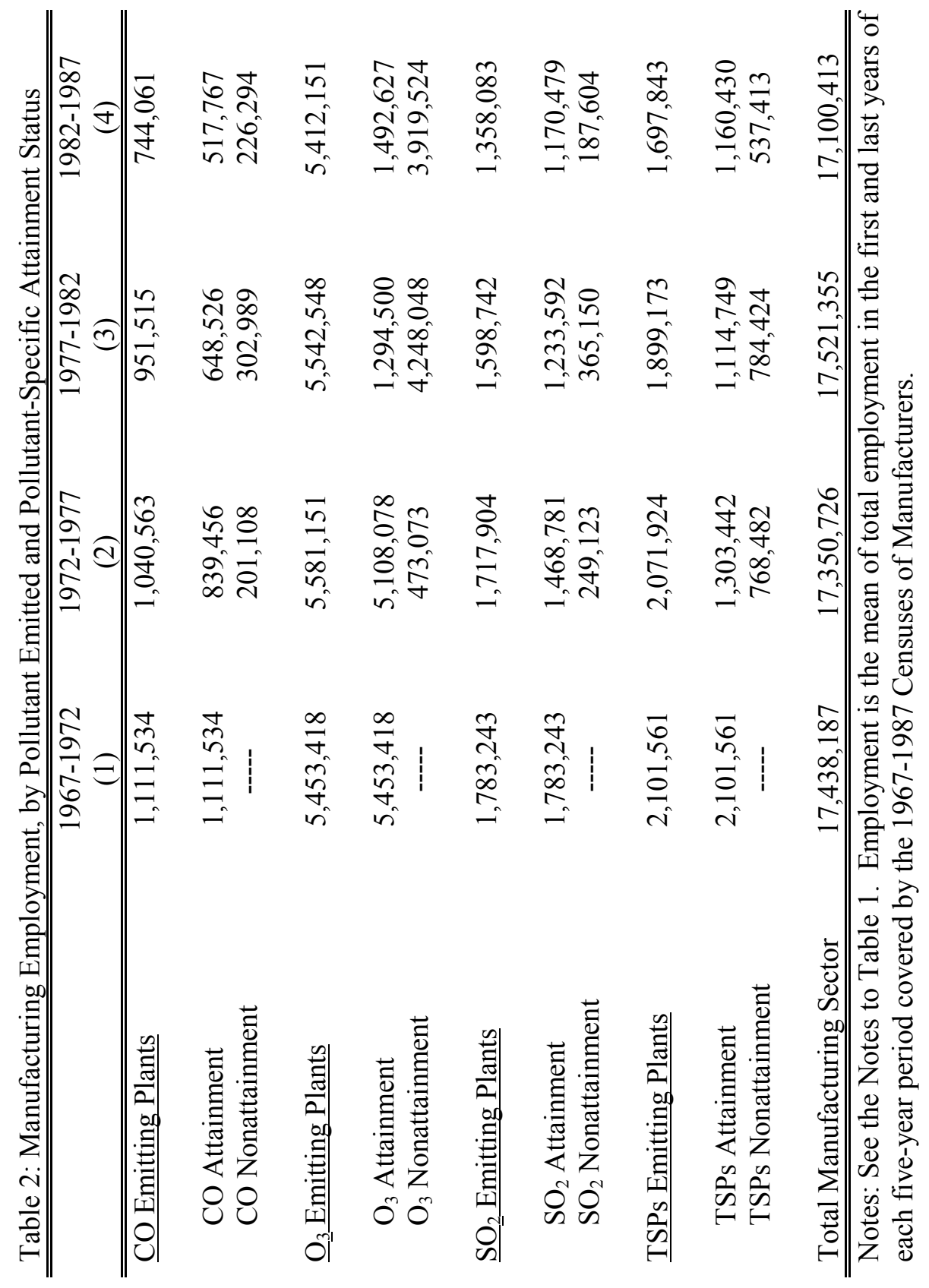




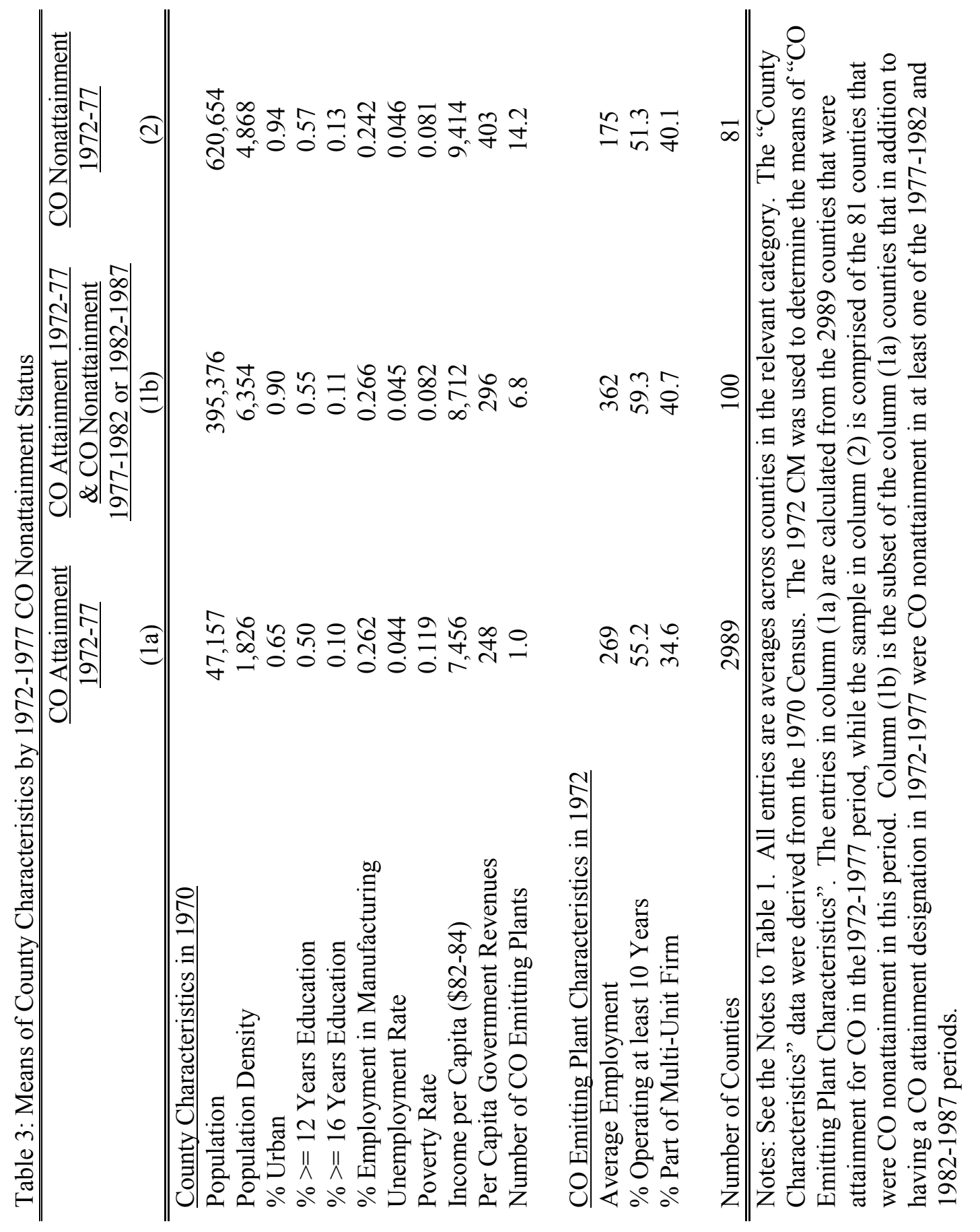




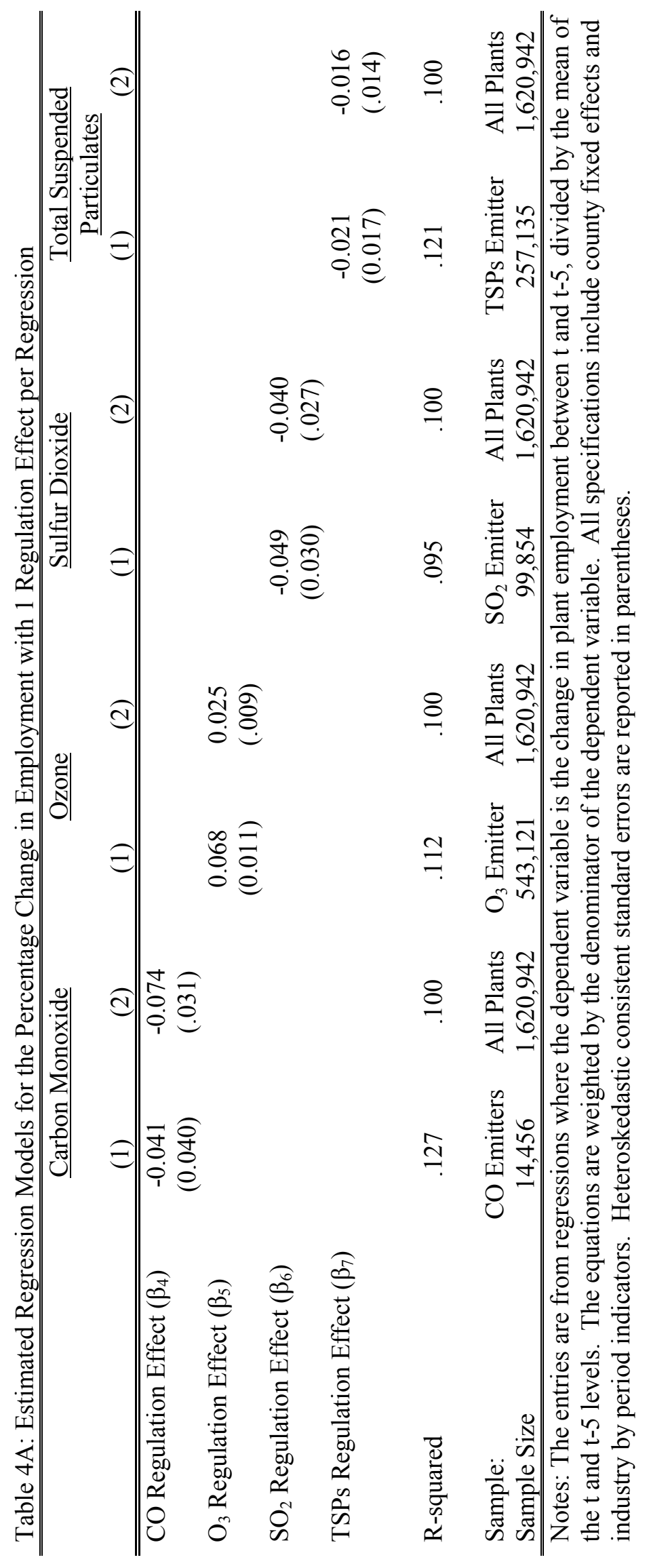


Table 4B: Estimated Regression Models for the Percentage Change in Employment

\begin{tabular}{lcccc}
\hline \hline & $(1)$ & $(2)$ & $(3)$ & $(4)$ \\
\hline \hline CO Regulation Effect $\left(\beta_{4}\right)$ & -0.084 & -0.075 & -0.086 & -0.163 \\
& $(0.032)$ & $(0.031)$ & $(0.030)$ & $(0.045)$ \\
& & & & \\
$\mathrm{O}_{3}$ Regulation Effect $\left(\beta_{5}\right)$ & 0.001 & 0.022 & -0.011 & -0.049 \\
& $(0.011)$ & $(0.010)$ & $(0.010)$ & $(0.015)$ \\
& & & & \\
$\mathrm{SO}_{2}$ Regulation Effect $\left(\beta_{6}\right)$ & -0.004 & -0.016 & 0.003 & 0.001 \\
& $(0.029)$ & $(0.028)$ & $(0.029)$ & $(0.036)$ \\
& & & & \\
TSPs Regulation Effect $\left(\beta_{7}\right)$ & -0.024 & -0.010 & -0.020 & -0.024 \\
& $(0.014)$ & $(0.013)$ & $(0.013)$ & $(0.024)$ \\
& & & & \\
R-squared & 0.109 & 0.119 & 0.144 & 0.504 \\
& & & & \\
Industry $\times$ Period Effects & Yes & Yes & Yes & Yes \\
Nonattainment $\times$ Period Effects & Yes & Yes & No & No \\
County Effects & No & Yes & No & No \\
County $\times$ Period Effects & No & No & Yes & Yes \\
Plant Effects & No & No & No & Yes \\
\hline \hline
\end{tabular}

Notes: See the notes to Table 4A. In all specifications, the sample includes the $1,620,942$ plant observations with nonmissing and nonnegative employment. The mean five-year growth rate of employment in the sample was $-1.4 \%$. 
Table 5: Estimated Regression Models for the Percentage Change in Capital Stock and Shipments

\begin{tabular}{|c|c|c|c|c|}
\hline & $(1)$ & $(2)$ & $(3)$ & $(4)$ \\
\hline \multicolumn{5}{|l|}{ Capital Stock } \\
\hline CO Regulation Effect $\left(\beta_{4}\right)$ & $\begin{array}{c}-0.047 \\
(0.043)\end{array}$ & $\begin{array}{l}-0.047 \\
(0.042)\end{array}$ & $\begin{array}{l}-0.097 \\
(0.043)\end{array}$ & $\begin{array}{l}-0.092 \\
(0.062)\end{array}$ \\
\hline $\mathrm{O}_{3}$ Regulation Effect $\left(\beta_{5}\right)$ & $\begin{array}{l}-0.009 \\
(0.022)\end{array}$ & $\begin{array}{c}0.016 \\
(0.021)\end{array}$ & $\begin{array}{c}-0.001 \\
(0.021)\end{array}$ & $\begin{array}{l}-0.041 \\
(0.029)\end{array}$ \\
\hline $\mathrm{SO}_{2}$ Regulation Effect $\left(\beta_{6}\right)$ & $\begin{array}{l}-0.024 \\
(0.047)\end{array}$ & $\begin{array}{c}-0.048 \\
(0.049)\end{array}$ & $\begin{array}{l}-0.057 \\
(0.055)\end{array}$ & $\begin{array}{l}-0.063 \\
(0.048)\end{array}$ \\
\hline TSPs Regulation Effect $\left(\beta_{7}\right)$ & $\begin{array}{c}0.026 \\
(0.027)\end{array}$ & $\begin{array}{c}0.042 \\
(0.025)\end{array}$ & $\begin{array}{c}0.010 \\
(0.024)\end{array}$ & $\begin{array}{l}-0.043 \\
(0.039)\end{array}$ \\
\hline $\begin{array}{l}\text { R-squared } \\
\text { Shipments }\end{array}$ & 0.074 & 0.109 & 0.155 & 0.462 \\
\hline CO Regulation Effect $\left(\beta_{4}\right)$ & $\begin{array}{l}-0.058 \\
(0.029)\end{array}$ & $\begin{array}{l}-0.036 \\
(0.029)\end{array}$ & $\begin{array}{l}-0.072 \\
(0.029)\end{array}$ & $\begin{array}{l}-0.146 \\
(0.046)\end{array}$ \\
\hline $\mathrm{O}_{3}$ Regulation Effect $\left(\beta_{5}\right)$ & $\begin{array}{c}0.022 \\
(0.018)\end{array}$ & $\begin{array}{c}0.048 \\
(0.018)\end{array}$ & $\begin{array}{c}0.019 \\
(0.016)\end{array}$ & $\begin{array}{l}-0.032 \\
(0.024)\end{array}$ \\
\hline $\mathrm{SO}_{2}$ Regulation Effect $\left(\beta_{6}\right)$ & $\begin{array}{l}-0.007 \\
(0.033)\end{array}$ & $\begin{array}{l}-0.026 \\
(0.030)\end{array}$ & $\begin{array}{l}-0.027 \\
(0.030)\end{array}$ & $\begin{array}{l}-0.010 \\
(0.039)\end{array}$ \\
\hline TSPs Regulation Effect $\left(\beta_{7}\right)$ & $\begin{array}{l}-0.014 \\
(0.019)\end{array}$ & $\begin{array}{l}-0.002 \\
(0.018)\end{array}$ & $\begin{array}{l}-0.010 \\
(0.018)\end{array}$ & $\begin{array}{l}-0.032 \\
(0.034)\end{array}$ \\
\hline R-squared & 0.127 & 0.142 & 0.185 & 0.516 \\
\hline Industry $\times$ Period Effects & Yes & Yes & Yes & Yes \\
\hline Nonattainment $\times$ Period Effects & Yes & Yes & No & No \\
\hline County Fixed Effects & No & Yes & No & No \\
\hline County $\times$ Period Fixed Effects & No & No & Yes & Yes \\
\hline Plant Fixed Effects & No & No & No & Yes \\
\hline
\end{tabular}

Notes: See the Notes to Table 4B. The sample sizes are 1,607,332 plant observations for the capital stock regressions and 1,737,753 for shipments. The mean five-year growth rates of capital stock and shipments are $36.5 \%$ and $10.0 \%$, respectively. 


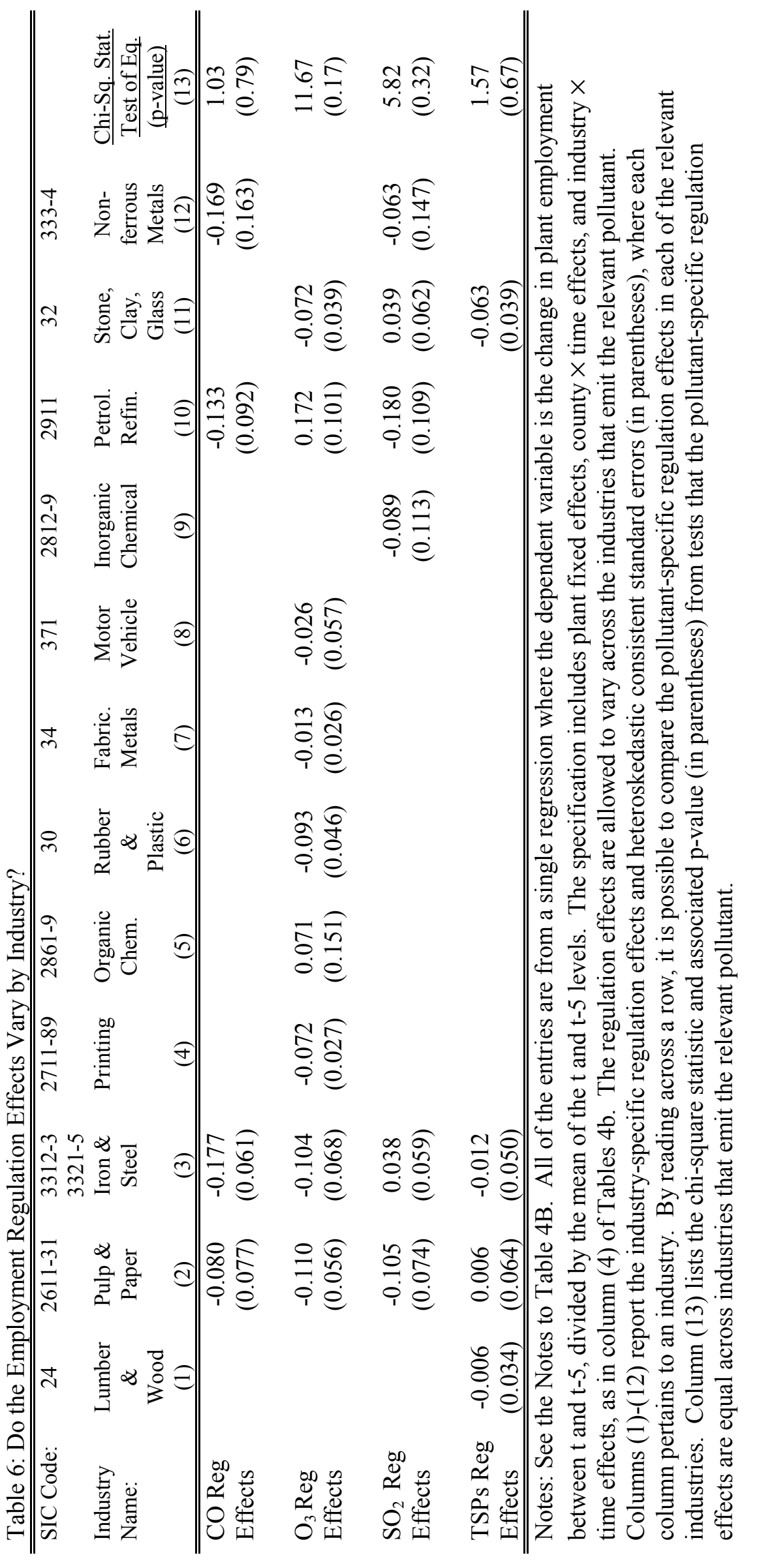


Table 7: Probing the Robustness of the Regulation Effects

\begin{tabular}{|c|c|c|c|c|}
\hline & $\begin{array}{c}\text { Base } \\
\text { Specification } \\
(0)\end{array}$ & $\begin{array}{c}\text { Dynamic } \\
\text { Model } \\
(1)\end{array}$ & $\begin{array}{l}\text { Limit Sample } \\
\text { to "Stayers" } \\
(2)\end{array}$ & $\begin{array}{c}4.5 \% \text { Emission } \\
\text { Rule } \\
(3)\end{array}$ \\
\hline \multicolumn{5}{|l|}{ Total Employment } \\
\hline$\overline{\text { CO Regulation Effect }}\left(\beta_{4}\right)$ & $\begin{array}{c}-0.086 \\
(0.030)\end{array}$ & $\begin{array}{l}-0.094 \\
(0.028)\end{array}$ & $\begin{array}{c}-0.059 \\
(0.023)\end{array}$ & $\begin{array}{c}-0.097 \\
(0.028)\end{array}$ \\
\hline $\mathrm{O}_{3}$ Regulation Effect $\left(\beta_{5}\right)$ & $\begin{array}{l}-0.011 \\
(0.010)\end{array}$ & $\begin{array}{l}-0.007 \\
(0.010)\end{array}$ & $\begin{array}{l}-0.019 \\
(0.008)\end{array}$ & $\begin{array}{l}-0.016 \\
(0.010)\end{array}$ \\
\hline $\mathrm{SO}_{2}$ Regulation Effect $\left(\beta_{6}\right)$ & $\begin{array}{c}0.003 \\
(0.029)\end{array}$ & $\begin{array}{c}0.005 \\
(0.027)\end{array}$ & $\begin{array}{c}0.010 \\
(0.021)\end{array}$ & $\begin{array}{c}0.006 \\
(0.028)\end{array}$ \\
\hline TSPs Regulation Effect $\left(\beta_{7}\right)$ & $\begin{array}{l}-0.020 \\
(0.013)\end{array}$ & $\begin{array}{c}-0.013 \\
(0.014)\end{array}$ & $\begin{array}{c}-0.022 \\
(0.011)\end{array}$ & $\begin{array}{c}-0.013 \\
(0.013)\end{array}$ \\
\hline \multicolumn{5}{|l|}{ Capital Stock } \\
\hline 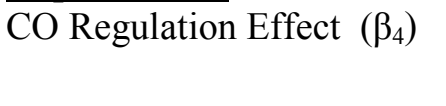 & $\begin{array}{c}-0.097 \\
(0.043)\end{array}$ & $\begin{array}{c}-0.134 \\
(0.041)\end{array}$ & $\begin{array}{l}-0.110 \\
(0.033)\end{array}$ & $\begin{array}{l}-0.115 \\
(0.040)\end{array}$ \\
\hline $\mathrm{O}_{3}$ Regulation Effect $\left(\beta_{5}\right)$ & $\begin{array}{c}-0.001 \\
(0.021)\end{array}$ & $\begin{array}{c}-0.007 \\
(0.021)\end{array}$ & $\begin{array}{l}-0.021 \\
(0.016)\end{array}$ & $\begin{array}{c}-0.009 \\
(0.020)\end{array}$ \\
\hline $\mathrm{SO}_{2}$ Regulation Effect $\left(\beta_{6}\right)$ & $\begin{array}{c}-0.057 \\
(0.055)\end{array}$ & $\begin{array}{c}-0.085 \\
(0.045)\end{array}$ & $\begin{array}{c}-0.032 \\
(0.036)\end{array}$ & $\begin{array}{c}-0.006 \\
(0.052)\end{array}$ \\
\hline TSPs Regulation Effect $\left(\beta_{7}\right)$ & $\begin{array}{c}0.010 \\
(0.024)\end{array}$ & $\begin{array}{c}0.002 \\
(0.024)\end{array}$ & $\begin{array}{c}-0.038 \\
(0.021)\end{array}$ & $\begin{array}{c}0.010 \\
(0.033)\end{array}$ \\
\hline \multicolumn{5}{|l|}{ Shipments } \\
\hline 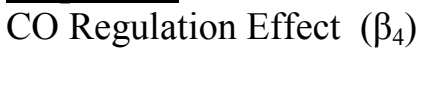 & $\begin{array}{c}-0.072 \\
(0.029)\end{array}$ & $\begin{array}{c}-0.092 \\
(0.027)\end{array}$ & $\begin{array}{l}-0.048 \\
(0.024)\end{array}$ & $\begin{array}{c}-0.075 \\
(0.027)\end{array}$ \\
\hline $\mathrm{O}_{3}$ Regulation Effect $\left(\beta_{5}\right)$ & $\begin{array}{c}0.019 \\
(0.016)\end{array}$ & $\begin{array}{l}-0.019 \\
(0.016)\end{array}$ & $\begin{array}{c}0.000 \\
(0.015)\end{array}$ & $\begin{array}{c}0.016 \\
(0.016)\end{array}$ \\
\hline $\mathrm{SO}_{2}$ Regulation Effect $\left(\beta_{6}\right)$ & $\begin{array}{c}-0.027 \\
(0.030)\end{array}$ & $\begin{array}{c}-0.054 \\
(0.025)\end{array}$ & $\begin{array}{l}-0.023 \\
(0.025)\end{array}$ & $\begin{array}{l}-0.020 \\
(0.030)\end{array}$ \\
\hline TSPs Regulation Effect $\left(\beta_{7}\right)$ & $\begin{array}{l}-0.010 \\
(0.018) \\
\end{array}$ & $\begin{array}{l}-0.054 \\
(0.016) \\
\end{array}$ & $\begin{array}{l}-0.037 \\
(0.015) \\
\end{array}$ & $\begin{array}{c}0.008 \\
(0.020) \\
\end{array}$ \\
\hline
\end{tabular}

Notes: See Notes to Tables $4 \mathrm{~b}$ and 5. The entries are the estimated regulation effects and heteroskedastic standard errors (in parentheses) from separate regressions for the three dependent variables. The dependent variable is denoted in bold and underlined. Each column represents a different specification or sample. All specifications include county $\times$ period effects, and industry $\times$ period effects. The entries in column (0) are taken from column (3) of Tables $4 \mathrm{~b}$ (employment) and 5 (capital stock and shipments) and should be compared to the other columns. In column (1), the lagged dependent variable is included as a regressor and its effect is allowed to vary by the pollutant emitted. The sample size is 884,812 for employment, 921,403 for capital stock, and 944,596 for shipments. In column (2), the sample is limited to "stayer" plants and the respective sample sizes are 762,513, 764,115, and 768,096. In column (3), plants are classified as an emitter of a pollutant if they account for at least $4.5 \%$ of industrial sector emissions (see Appendix Table 2). 


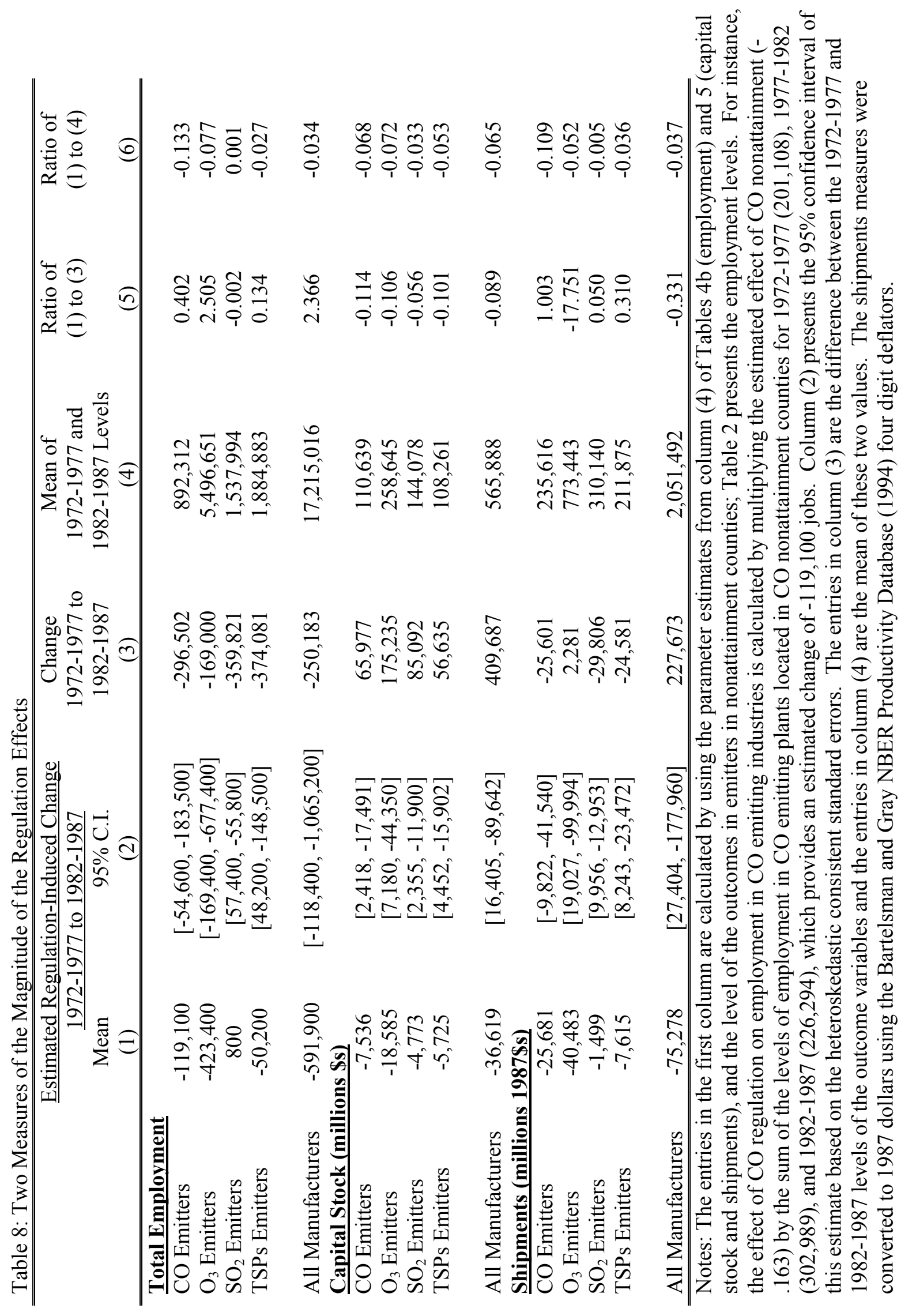


Appendix Table 1: Selected National Ambient Air Quality Standards

Pollutant Maximum Allowable Concentration

(Primary Standard)

Nitrogen Dioxide

Annual arithmetic mean

.053 parts per million

Ozone

Max 1 hour concentration $\quad .12$ parts per million (after 1979)

.08 parts per million (through 1979)

$\underline{\text { Sulfur Dioxide }}$

Annual arithmetic mean

.03 parts per million

Max 24 hour concentration

.14 parts per million

Total Suspended Particulates

Annual geometric mean

75 micrograms per cubic meter

Max 24 hour concentration

260 micrograms per cubic meter

Carbon Monoxide

Max 8 hour concentration $\quad 9$ parts per million

Max 1 hour concentration 35 parts per million

Notes: A county is in violation of the ozone or carbon monoxide standards if it exceeds the standard more than once in a year. In the case of the nitrogen dioxide, sulfur dioxide, and total suspended particulates standards, a county is in violation if it exceeds the standard once during a calendar year. In 1987 the EPA began to switch their focus from the regulation of all particulates (i.e., TSPs) to small particulates (i.e., PM-10s). In 1997 the ozone standard was revised and the particulates standard was further modified to regulate even smaller particulates (i.e., PM-2.5s). 


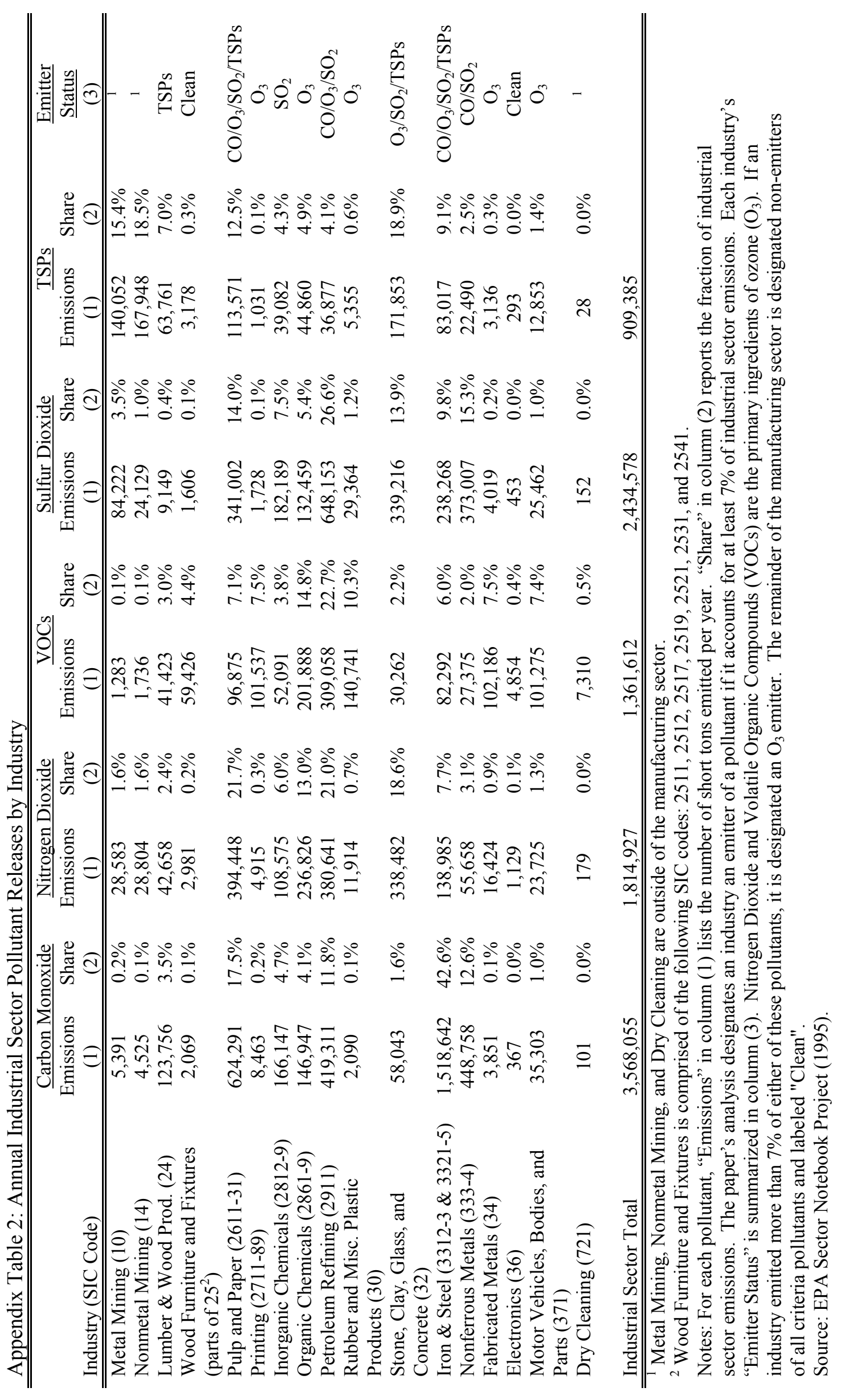



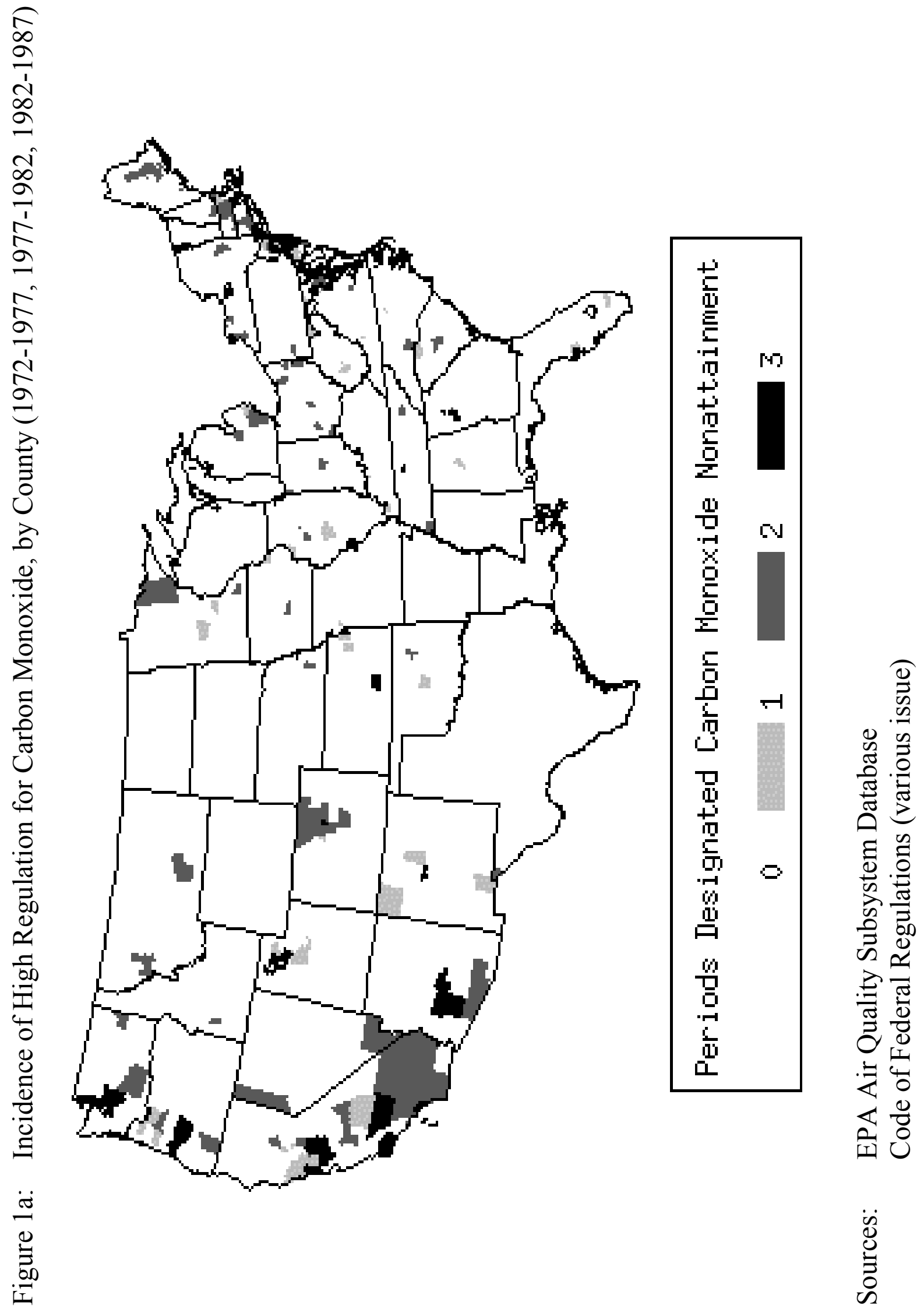

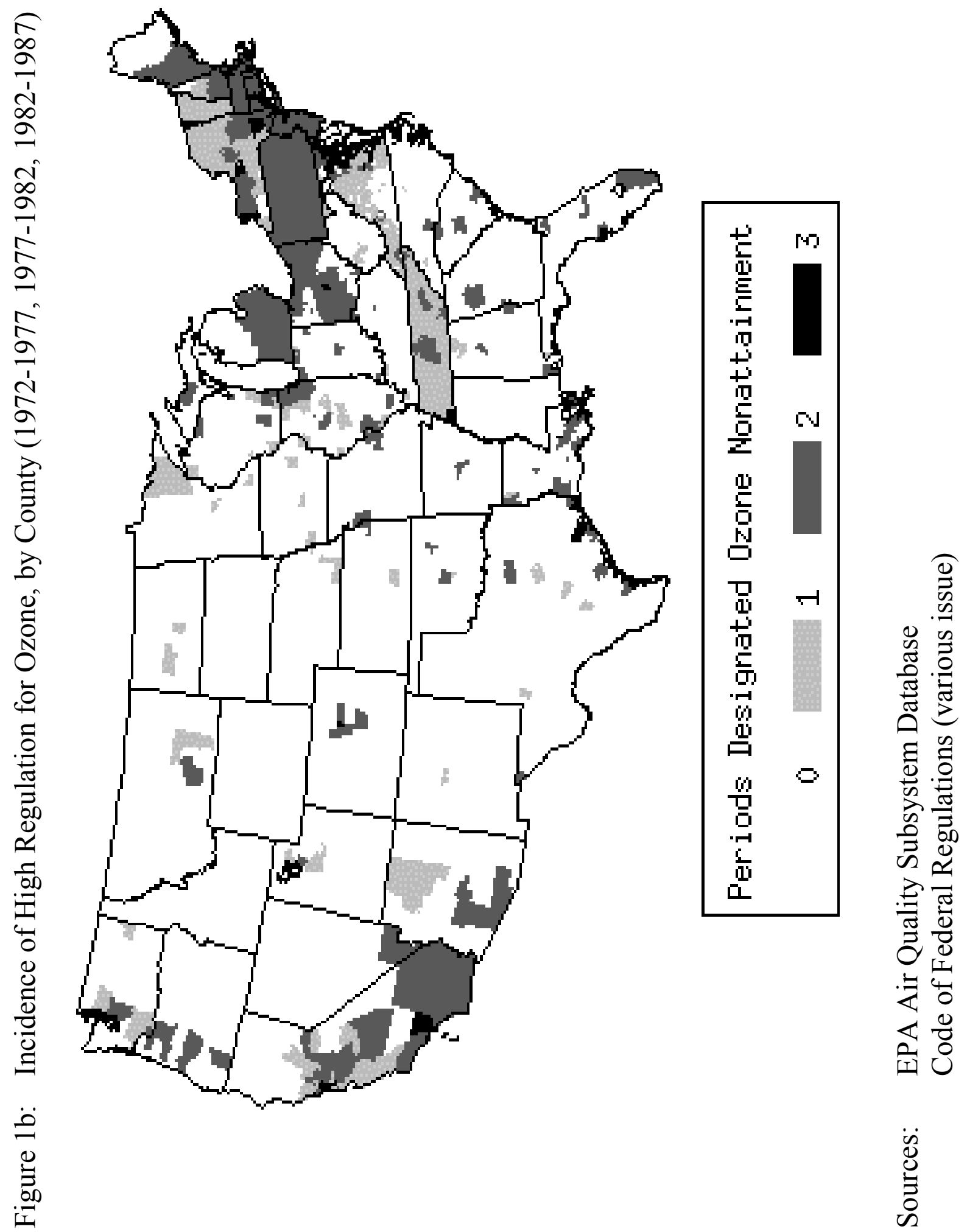

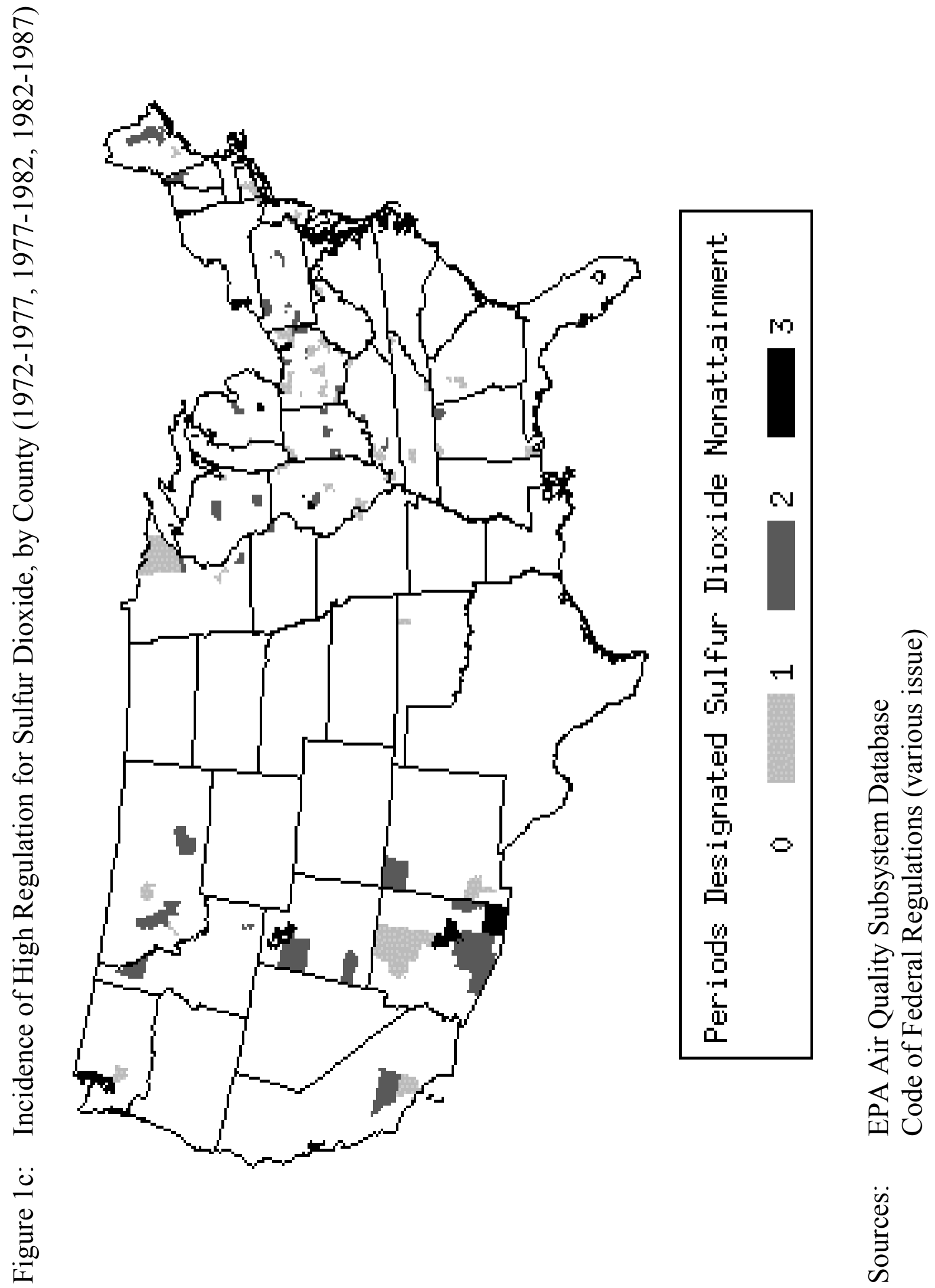


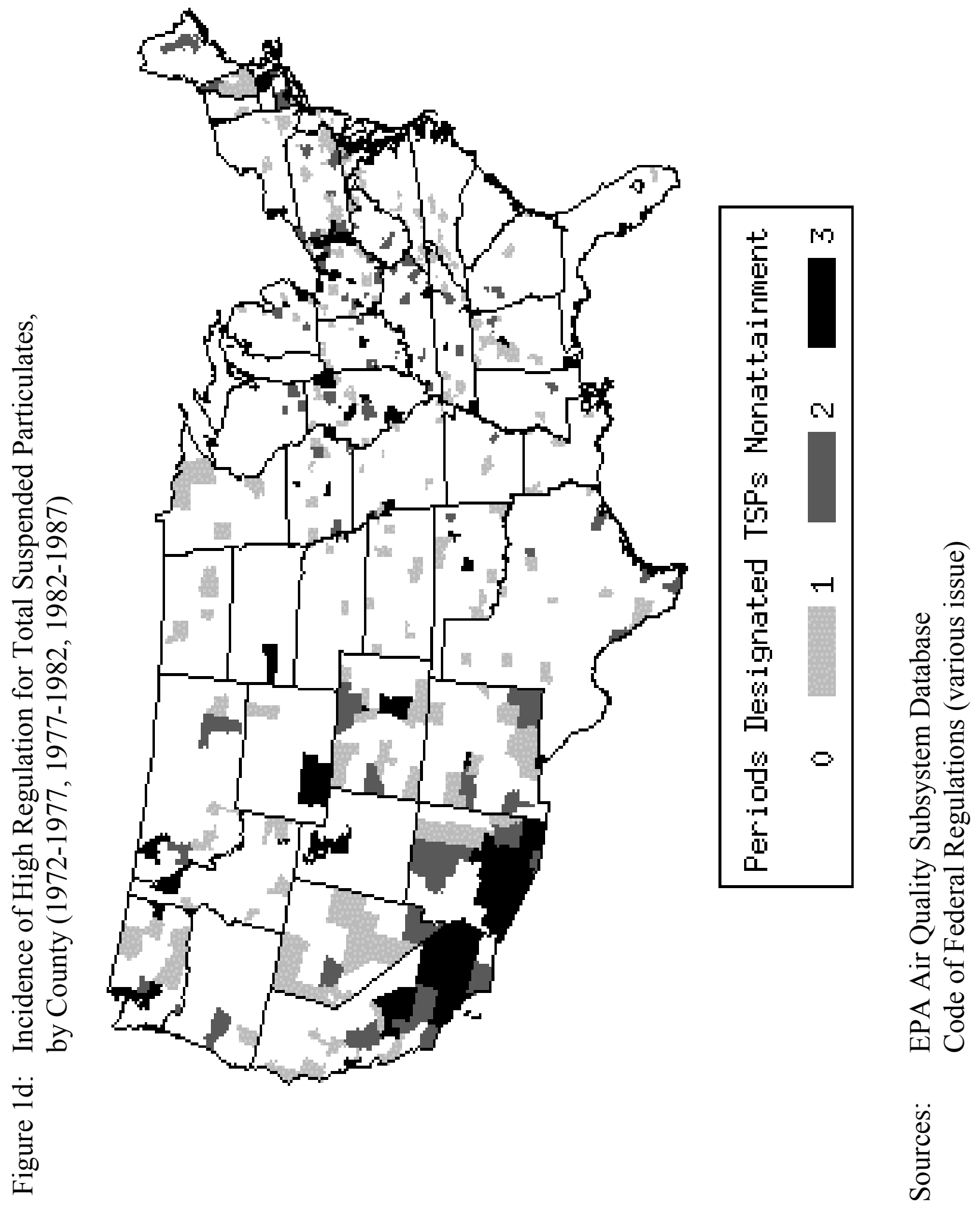

